Article

\title{
The Eco-Refurbishment of a 19th Century Terraced House: Energy and Cost Performance for Current and Future UK Climates
}

\section{Haniyeh Mohammadpourkarbasi and Steve Sharples *}

School of Architecture, University of Liverpool, Abercromby Square, Liverpool L69 7ZN, UK; E-Mail: hanimpk@liverpool.ac.uk

* Author to whom correspondence should be addressed; E-Mail: steve.sharples@liverpool.ac.uk; Tel.: +44-0151-794-2607.

Received: 20 December 2012; in revised form: 25 January 2013 / Accepted: 30 January 2013 / Published: 21 February 2013

\begin{abstract}
The UK government, responding to concerns over climate change impacts, has undertaken to reduce $\mathrm{CO}_{2}$ emissions to $80 \%$ of 1990 levels by 2050 . This scale of reduction will require major improvements in the energy efficiency of the existing UK building stock, which is the dominant consumer of fossil fuel-generated energy. Housing is a key sector, and since $70 \%$ of all current homes in the UK will still exist in 2050 then low carbon refurbishment is critical if $\mathrm{CO}_{2}$ reduction goals are to be met. This paper uses computer modeling to examine the annual operational energy performance, long term energy cost savings and internal thermal conditions for a 19th century terraced house that was eco-refurbished to near a Passivhaus standard. The dwelling was modeled for three locations (Edinburgh, Manchester and London) using current and future climate scenarios (2020s and 2050s under high carbon emission scenarios). Simulation results suggest that there would be very little diminution in heating demand in the future for the house with no refurbishment, whilst the eco-refurbishment produced a significant reduction in energy demand and $\mathrm{CO}_{2}$ emissions. Analysis of the payback period and net present value indicate that the economic optimum varies according to energy prices and that the high construction costs incurred for an eco-refurbishment to a near Passivhaus standard could not be justified in terms of a cost/benefit analysis.
\end{abstract}

Keywords: climate change; low carbon housing refurbishment; 19th century house 


\section{Introduction}

\subsection{Climate Change and the UK Housing Stock}

Fossil reserves are limited and finite and dependence on fossil-based energy should be minimized. In addition, recent climate change and global warming trends are believed to be due to the anthropogenic burning of fossil fuels. The target is to limit global warming to $2{ }^{\circ} \mathrm{C}$ above pre-industrial levels by 2050 and this requires keeping the concentration of $\mathrm{CO}_{2}$ below 400 parts per million. To achieve this an $80 \%$ reduction in emissions is needed [1]. According to the UK government's Department of Energy and Climate Change (DECC), in 2009, the residential sector accounted for $27 \%$ of final-user emissions. In order to meet the national target of $80 \% \mathrm{CO}_{2}$ reductions by 2050 , and to react to higher energy prices, it is critical that energy conservation in dwellings is a major performance objective in the design or rehabilitation of buildings. One step towards this objective in the UK is the requirement that from 2016 all new dwellings will have to be "zero carbon". Due to the very low numbers of new dwellings that are built each year the impact of this requirement will be incremental rather than immediately significant. Since $70 \%$ of all current homes in the UK will still exist in 2050, the drive to reduce carbon emissions from housing has shifted from new-build to retrofit. As a result, eco-refurbishment is critical if reduction goals are to be met [2].

This study considers the eco-refurbishment of a 19th century solid wall end-terraced house. The aim of the eco-refurbishment was to go beyond current UK thermal building regulations criteria and to try and achieve the more exacting German Passivhaus standard. This standard sets strict limits on the overall U-value of the external envelope $\left(\leq 0.15 \mathrm{~W} / \mathrm{m}^{2} \mathrm{~K}\right)$; airtightness@ $@ 50 \mathrm{~Pa}(\leq 0.6$ air changes per hour@50Pa and the use of mechanical ventilation with heat recovery); the elimination of cold bridges and the overall energy use for space heating $\left(\leq 15 \mathrm{kWh} / \mathrm{m}^{2}\right.$ of floor area per year). Compliance with the Passivhaus standard is checked by assessing the building using the Passivhaus Planning Package (PHPP) [3]. It is has been estimated that applying the Passivhaus standard to a typical UK building would reduce overall $\mathrm{CO}_{2}$ emissions by approximately $80 \%$ [4].

\subsection{Eco-Refurbishment}

In the context of carbon reduction, eco-refurbishment is about making buildings more thermally efficient and sustainable. The emphasis is on energy services, rather than energy purchase. It is about shifting the debate on to demand reduction rather than energy supply. As with the Passivhaus standard, eco-refurbishment also concentrates on three areas: improving the air-tightness of the house, reducing heat bridges, and, to a lesser extent, considering heat gain from the sun. In addition, eco-refurbishment means having energy services that use fuels with low carbon intensity and incorporating building integrated renewable energy systems. Essentially, a typical eco-refurbished house is air-tight and super-insulated, with mechanical ventilation and heat recovery (MVHR) to solve the issue of internal air quality and with a small heating element within the ventilation system. In addition, generally, windows are triple glazed [5]. The overall aim of eco-refurbishment is to find methods by which the UK government's commitment to an $80 \%$ reduction in $\mathrm{CO}_{2}$ emissions by 2050 (compared to 1990 levels) might be met within the existing housing stock. 


\subsection{Case Study}

The dwelling used for the eco-refurbishment study was a solid wall, 19th century terraced house in Liverpool. In March 2009 the UK's Technology Strategy Board (TSB) launched a competition, Retrofit for the Future, to encourage and enable building and renovation companies to retrofit and refurbish existing housing to make deep cuts in carbon emissions [6]. The Retrofit for the Future targets were linked to the Climate Change Act and, for the purpose of the competition, the following targets were set:

1. Maximum $\mathrm{CO}_{2}$ emissions $-17 \mathrm{~kg} / \mathrm{m}^{2} \mathrm{yr}$;

2. Maximum primary energy use $-115 \mathrm{kWh} / \mathrm{m}^{2} \mathrm{yr}$.

The primary energy consumption figure includes all the energy used in the house, including that for appliances (white goods) and consumer electronics [6]. The Retrofit for the Future competition was looking for creativity in developing 100 "exemplar" retrofit projects across the UK. The TSB offered $100 \%$ funding to each proposal and eventually 87 schemes were approved. Six were in the North West of England, including the terraced house, which was chosen as the case study for this research project [7]. Figures 1 and 2 show the selected case study which was refurbished by the Plus Dane Group with the aim of achieving Passivhaus standards as far as possible by applying 21st century solutions to a 19th century end terraced house. Passivhaus and/or sustainability principles were introduced in the demonstration project. The retrofit of the building included: very high levels of insulation, timber framed triple glazed windows, very high levels of airtightness@50Pa (1.0 ACH@50Pa), mechanical ventilation with heat recovery, solar gain via a new conservatory, LED lighting in the kitchen and bathroom, and A-rated low energy appliances [7].

Figure 1. Terraced house plans.

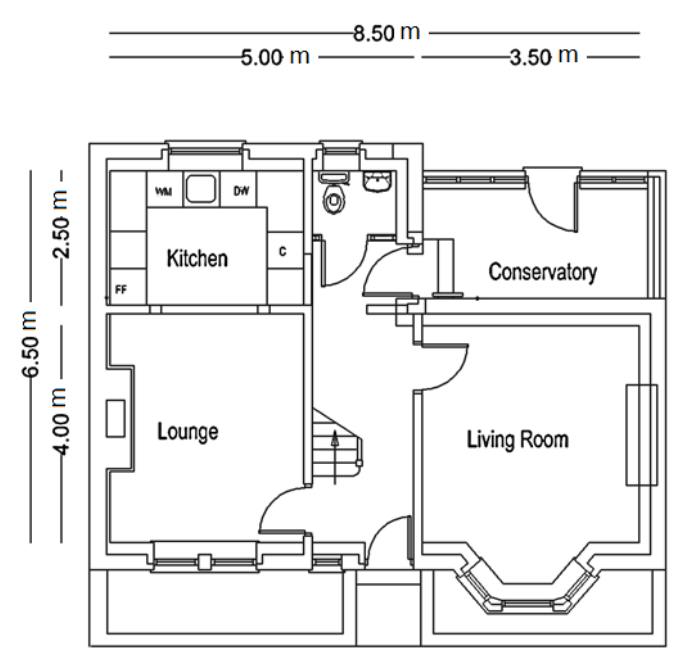

Ground Floor
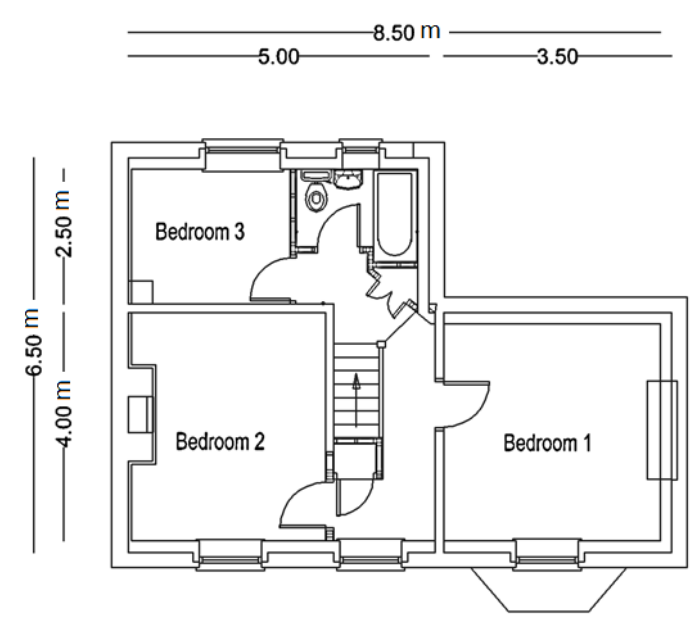

First Floor 
Figure 2. Terraced house after refurbishment.

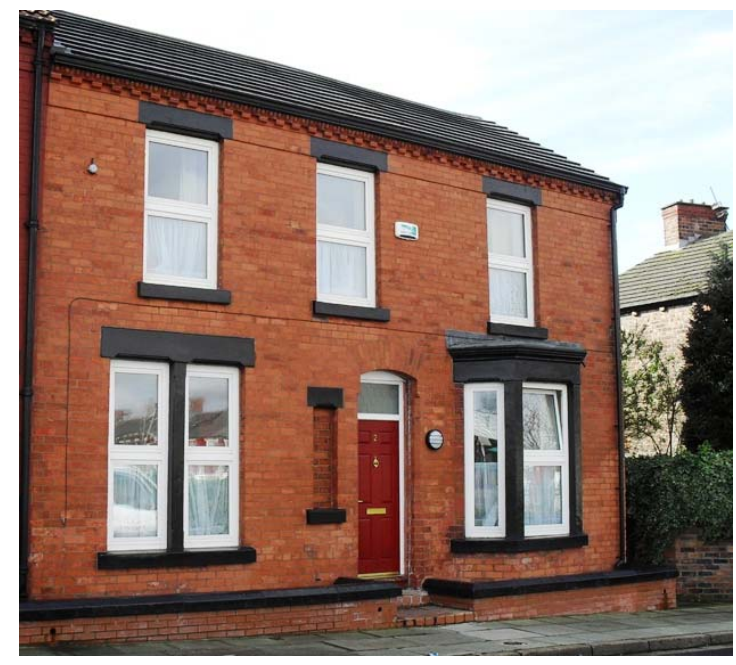

There were several reasons for choosing this 19th century terraced house as a case study of the feasibility of eco-refurbishment to a Passivhaus standard. Firstly, although over 20,000 Passivhaus accredited properties exist, the UK has only three of them. Secondly, Passivhaus refurbishment has not been tried before in the UK on an old terraced house. Thirdly, virtually all old terraced housing has a single skin, uninsulated solid wall structure, making them hard and expensive to treat and therefore not many have been subject to major refurbishment [8]. Finally, with more than 6 million 19th century terrace houses in the UK, they represent an important part of the country's housing resource and architectural heritage. Consequently, research on the experience of Passivhaus and low energy retrofit of such buildings can examine the challenges and opportunities of significant retrofits in conservation areas.

\subsection{Research Objectives}

The primary objective of this paper was to evaluate the benefits of sustainable refurbishment on the energy performance of 19th century type end-terrace houses under current and future climates. To do so a regional approach was adopted to assess innovations in the eco-refurbishment agenda. Locally and regionally, UK housing has quite different characteristics. There is also a geographical diversity, which causes different energy demands in different parts of the UK. Heating demand is typically higher in Scottish cities than in, say, Manchester, whilst the changing climate may lead to a significant increase in demand for summer cooling in London and the south east of the UK, but not necessarily elsewhere. A second objective of this study was to consider how to apply the knowledge and technologies of eco-refurbishment in the context of future climates and to make well-founded decisions based on these considerations. A final objective was to see how savings (which are increased by reusing and refurbishing an existing building) might relate to the operational costs during the building's life cycle.

\section{Methodology}

\subsection{Modelling}

The 19th century type end-terraced house was modeled (before and after refurbishment) using the advanced thermal simulation package DesignBuilder. As there was not enough information about the 
previous condition of the house the characteristics of the typical terraced houses in the neighborhood were studied to create a pre-refurbishment model of the existing house in the chosen software (DesignBuilder). Tables 1 and 2 compare the pre and post refurbishment thermal features of the house. The occupancy densities and occupied period profiles were selected based on the real house schedules obtained from monitoring results for a family of four (two adults and two children). In addition, internal heat gain allowances were selected according to the activity of each zone in the building. Then, simulations were carried out with all treated zones assumed to be kept to a nominal set point temperature of $21{ }^{\circ} \mathrm{C}$ and heated to set points of between $19{ }^{\circ} \mathrm{C}$ and $21{ }^{\circ} \mathrm{C}$ (depending on the nature of usage). Current weather data for Liverpool were used to evaluate the effect of eco-refurbishment on energy consumption and $\mathrm{CO}_{2}$ emissions.

Table 1. Pre-refurbishment thermal features of a 19th century terraced house [9].

\begin{tabular}{ccc}
\hline & Element & Fabric U-value \\
\cline { 2 - 3 } & Insulated roof-100mm mineral wool & $0.40 \mathrm{~W} / \mathrm{m}^{2} \mathrm{~K}$ \\
Typical existing construction & Solid Walls-215mm thick brick work & $2.10 \mathrm{~W} / \mathrm{m}^{2} \mathrm{~K}$ \\
& Uninsulated suspended timber floor & $0.50 \mathrm{~W} / \mathrm{m}^{2} \mathrm{~K}$ \\
& Windows-single glazed timber frames & $4.80 \mathrm{~W} / \mathrm{m}^{2} \mathrm{~K}$ \\
& Doors-unglazed solid timber & $3.00 \mathrm{~W} / \mathrm{m}^{2} \mathrm{~K}$ \\
\hline
\end{tabular}

Table 2. Post-refurbishment thermal features of the terraced house [10].

\begin{tabular}{ccc}
\hline & Element & Fabric U-value \\
\cline { 2 - 3 } & Insulated roof-400mm Rockwool & $0.15 \mathrm{~W} / \mathrm{m}^{2} \mathrm{~K}$ \\
Upgraded fabric construction & Solid wall-internal insulation (using Supa Wall) & $0.11 \mathrm{~W} / \mathrm{m}^{2} \mathrm{~K}$ \\
& Concrete floor slab, Supa floor panels & $0.12 \mathrm{~W} / \mathrm{m}^{2} \mathrm{~K}$ \\
& Windows-triple glazed & $0.78 \mathrm{~W} / \mathrm{m}^{2} \mathrm{~K}$ \\
& FD20 rated fire doors in frames containing & $1.00 \mathrm{~W} / \mathrm{m}^{2} \mathrm{~K}$ \\
\hline
\end{tabular}

In addition, the energy and $\mathrm{CO}_{2}$ performances of the same pre and post refurbishment dwellings were examined for current and future climates at three other cities across the UK.

\subsection{Weather Data for Simulation}

The Intergovernmental Panel on Climate Change (IPCC) stated in its Technical Summary for their Fourth Assessment Report that an increase in global average surface temperature would occur towards the end of the 21 century [11]. For UK specific climate projections the UK Climate Impacts Programme (UKCIP), a UK based agency, in conjunction with the UK's Meteorological Office's Hadley Centre, published its first climate change projections in 1998, which were substantially updated in 2002 and again in 2009. For the purpose of this research climate change scenarios and future hourly weather data released by the UK's Charted Institution of Building Services Engineers (CIBSE), which incorporated the UKCIP02 projections for three timelines (2020s, 2050s, 2080s) and four carbon emissions scenarios (low, medium-low, medium-high and high), have been used. These data are in TRY (Test Reference Year) format but need to be generated in the EPW (EnergyPlus Weather) format to be readable in DesignBuilder. No TRY files existed for Liverpool at the time of this study and only 
current weather data in the EPW format were available. However, current TRY weather data were available for three UK locations (Edinburgh, Manchester and London). These TRY files were morphed in to future weather data using the software CCWeatherGen [12] (time slices: 2020s, 2050s, 2080s; carbon emission scenarios: low, medium and high). Therefore, the same dwelling was assumed to be located in these three cities and simulated using these weather data to model the effect of climate change and geographical diversity on $\mathrm{CO}_{2}$ emissions, heating and cooling energy usage. In this paper only the results from 2020 to 2050 high emission scenarios will be presented.

CCWeatherGen transforms CIBSE/Met Office TRY/DSY weather files into future EPW weather files [12]. UKCIP02 data were used for this research because, at the time of the analysis, CCWeatherGen used the UKCIP2002 climate change scenario predictions to generate future weather files that were ready to use in building performance simulation programs (i.e., in EPW format). The PROMETHEUS project in Exeter University has recently produced a number of EPW future weather files using the UKCP09 weather generator, which can be used to "future-proof" buildings against predicted climate change. The key difference between UKCP02 and UKCP09 is the use of probabilistic information within UKCP09, which represents a random sampling of a probability distribution function and hence the probability of a particular level of climate change [13].

\subsection{Model Validation}

Simulation software is a useful tool to study the impact of climate change on building energy performance. However, it is important to validate the results from simulation to ensure confidence in the results. The Plus Dane Group used the Passive House Planning Package (PHPP) for its simulation of the terraced house (Table 3). Their predicted results were used for initial validation of the model created in DesignBuilder. This preliminary comparison showed a small percentage difference between the PHPP and DesignBuilder outcomes.

Table 3. Comparison of PHPP results with DesignBuilder for terraced house pre-refurbishment.

\begin{tabular}{ccc} 
Measures & PHPP & DesignBuilder \\
\hline Annual $\mathrm{CO}_{2}$ emissions $\left(\mathrm{kg} \mathrm{CO} / \mathrm{m}^{2} \mathrm{yr}\right)$ & 77 & 72 \\
Primary energy requirement $\left(\mathrm{kWh} / \mathrm{m}^{2} \mathrm{yr}\right)$ & 380 & 320 \\
\hline
\end{tabular}

In addition, the Plus Dane Group has been monitoring many parameters in the house at five minute intervals since it was first occupied after refurbishment in November 2010. Large amounts of data have been measured such as internal carbon dioxide levels, floor, wall and ceiling surface temperatures, external air temperatures and electricity, water and gas consumption. One complete year of monitored data was made available for this study. These data were compared with the DesignBuilder simulations as part of the validation procedure. To start the validation a comparison of the weather data was necessary. DesignBuilder simulation results were based on 2002 CIBSE weather data whilst the monitoring was carried out between November 2010 and October 2011. Figure 3 shows 2002 (CIBSE) average monthly external air temperatures with 2010 (measured) weather data for Liverpool. There is generally reasonable agreement but it can be seen that the average temperatures generally increased over the period. 
Figure 3. Comparison of 2002 (CIBSE) weather data (external air temperature in ${ }^{\circ} \mathrm{C}$ ) with 2010 (monitored results) weather data for Liverpool, UK.

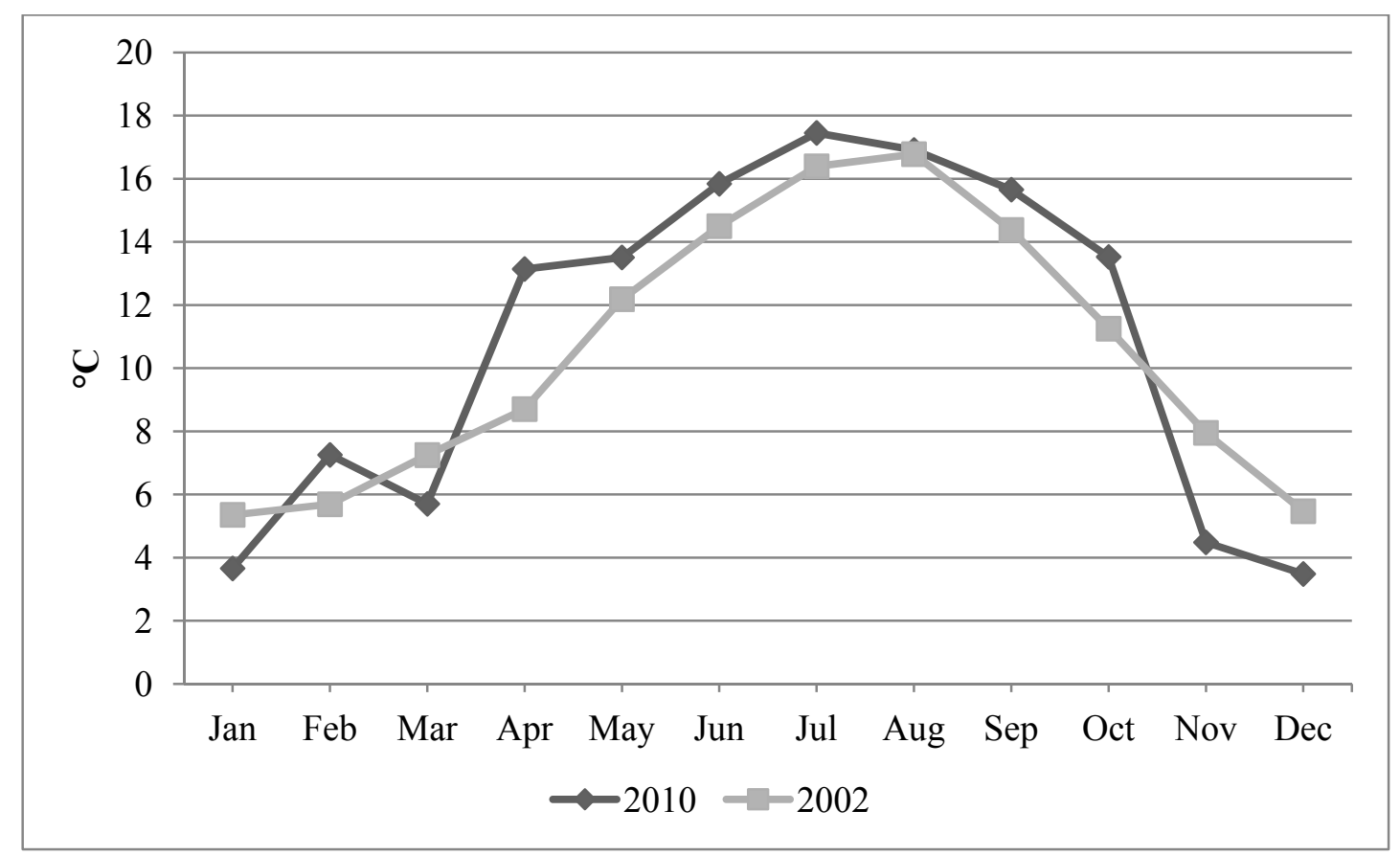

A comparison of monitored and predicted annual $\mathrm{CO}_{2}$ emissions and primary energy requirements can be seen in Table 4. There are small differences between the results, which could be attributed to the small differences in the weather data.

Table 4. Monitored results and DesignBuilder predictions for the refurbished terraced house.

\begin{tabular}{ccc}
\hline Measures & Monitored & DesignBuilder \\
\hline Annual $\mathrm{CO}_{2}$ emissions $\left(\mathrm{kg} \mathrm{CO} / \mathrm{m}^{2} \mathrm{yr}\right)$ & 16 & 18 \\
Primary energy requirement $\left(\mathrm{kWh} / \mathrm{m}^{2} \mathrm{yr}\right)$ & 105 & 119 \\
\hline
\end{tabular}

Having validated the program made it possible to investigate how the same refurbished terraced house might perform in different current and future climate scenarios.

\subsection{Whole Life-Cycle Costing}

In the process of fulfilling an $80 \%$ reduction goal and meeting eco-refurbishment benchmarks, one of the most important questions is that of economic feasibility. The question arises due to several potential alternative investment options and the importance of finding the most economical choice in the long term. In this paper a Whole Life Cycle Costing (WLCC) technique has been used for comparative cost assessments over a 40 year period of time, taking into account the present value of initial capital costs, future operational costs and savings from this type of eco-refurbishment.

\subsubsection{Definition}

Whole Life Cycle Costs consider the total expense of a project over the six stages of Non-Construction Costs, Construction Costs, Operation Costs (including energy expenditures), 
Maintenance Costs, Replacement Costs and Disposal Costs. For the purpose of this paper the effects and savings on heating consumption from improving construction have been evaluated. The WLCC of fitting wall and roof insulation and replacing windows and doors has been assessed. The cost and effect of improvement and replacement of lighting and mechanical equipment are not considered in this part of the analysis.

Whole Life Cycle Cost is defined as [14]:

$$
W L C C=I C+\sum_{t=1}^{N} \frac{O C_{t}}{(1+r)^{t}}
$$

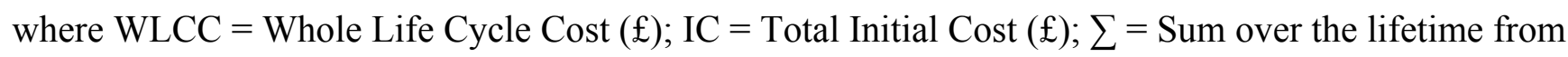
year 1 to year $\mathrm{N}$, where $\mathrm{N}=$ lifetime of appliance (years); $\mathrm{OC}_{\mathrm{t}}=$ Operating Cost $(\mathfrak{f}) ; \mathrm{r}=$ Discount rate; $\mathrm{t}=$ Year for which operating cost is being determined.

\subsubsection{Total Initial Costs Inputs}

For the purpose of this study, the initial cost of the project consists of the cost of new construction materials and labor. Table 5 shows the total initial outlay and capital cost of the construction improvement and replacement for the terraced house. All doors and windows were replaced.

Table 5. Cost breakdown for the terraced house's refurbishment.

\begin{tabular}{cccc}
\hline Item & Material & Labor & Total \\
\hline Insulation & $£ 12,000$ & $£ 7,000$ & $£ 19,000$ \\
New roof & $£ 1,950$ & $£ 2,000$ & $£ 3,950$ \\
Triple glazing and doors & $£ 18,200$ & $£ 2,000$ & $£ 20,200$ \\
Total initial cost of construction & - & - & $£ 43,150$ \\
\hline
\end{tabular}

\subsubsection{Operating Cost Inputs}

Energy expenditure, repair costs and maintenance costs all together are defined as the operating cost. The processes during the in-use life phase are an important factor as a significant proportion of the impact of the building occurs after construction and installation of systems. In this study, it is assumed that the life of the construction in this refurbished property will be more than 40 years. Any recurring impact (repair and maintenance costs) is not considered as the building was refurbished to have a very low maintenance cost. However, the maintenance costs of a building can contribute significantly to the total cost of it [15]. Required inputs for calculating operating costs are: energy consumption, energy cost savings, gas prices (the refurbished house is heated by gas), predicted gas price trends in the future and assumed discount rate.

\subsubsection{Heating Energy Savings}

The total annual heating energy saving is the difference between the heating consumptions of the original house and the retrofit house, and results from the lower gas heating consumption arising from a more efficient construction and lower heat losses through the insulation and triple-glazed windows. 


\subsubsection{Effect of Climate Change on Annual Savings}

It is not only regional weather differences but also climate change that will impact upon heating consumption in the pre and post-refurbished house. Accordingly, the annual savings change for different climate scenarios have been considered and predicted by running simulations for different types of weather scenarios (see Section 2.2).

\subsubsection{Instability of Future Gas Price and Annual Savings}

Experts in the field of energy economics believe that the main question about future gas prices is not "will prices rise?" but "by how much?" Figure 4 compares gas price projections from eight different sources [16].

Five elements that contribute to a consumer's energy bill are the wholesale cost of fuel, the cost of supply transmission, distribution and metering, the costs of Government/EU policy, VAT and supplier margins. Ofgem estimates shown in Table 6 confirm that wholesale fuel costs and the costs of supply are the largest elements effecting gas prices; incidentally, VAT has remained at 5\% since 1997 [17]. Therefore, less dependence on imports, more domestic production and the extent to which the technology is increasing, will have a big impact on gas prices. Shale gas, and in particular the process of "fracking" which is used to extract it, can be a solution for the first concern. In the USA a rapid revolution in gas production from "unconventional" sources-in particular shale and coal bed gas - has transformed the market. The USA is now self-sufficient in gas. Some analysts claim that this could also eventually happen in the UK [17].

Figure 4. DECC gas price projections, October 2011 [16].

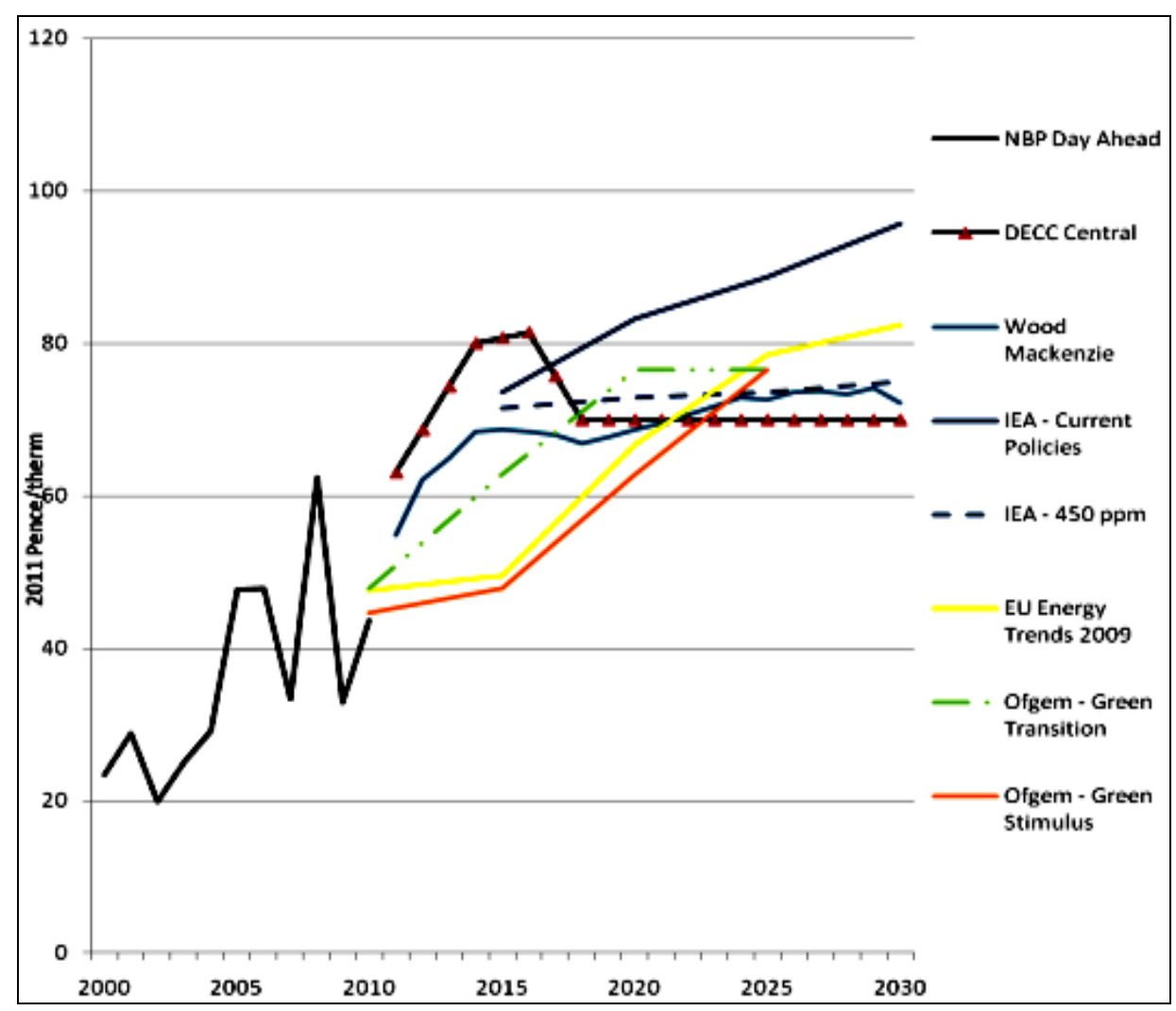


Table 6. Estimated contributory factors to domestic energy price rise February 2004 to January 2011.

Estimated increase in annual bill

\begin{tabular}{cc} 
Increase in unit costs due to & Gas\% \\
\hline Whole sale energy & 66 \\
Transmission, distribution and metering & 20 \\
Carbon price & - \\
Renewables & - \\
Energy efficiency funding & 7 \\
VAT & 5 \\
Overall price increase & 121 \\
Estimated increase in annual bill (2004 to 2010) & $£ 295$ \\
\hline
\end{tabular}

Energy prices will not remain constant in real terms over time but, by using historic data, it is possible to predict the range of probable future prices and have some idea of which prices are more likely to occur [18]. Figure 5 (which illustrates the average annual standard gas bills for a typical residential gas consumer for 16 years since 1996) shows that the price of gas is unstable in the UK and there is uncertainty in any assumption about constant or future gas prices [19]. Three "waves" of rising, falling and steady domestic gas prices since the late 1996s show that a rising price for gas is not the only possibility.

Figure 5. Average annual standard gas bills for a typical residential gas consumer since 1996.

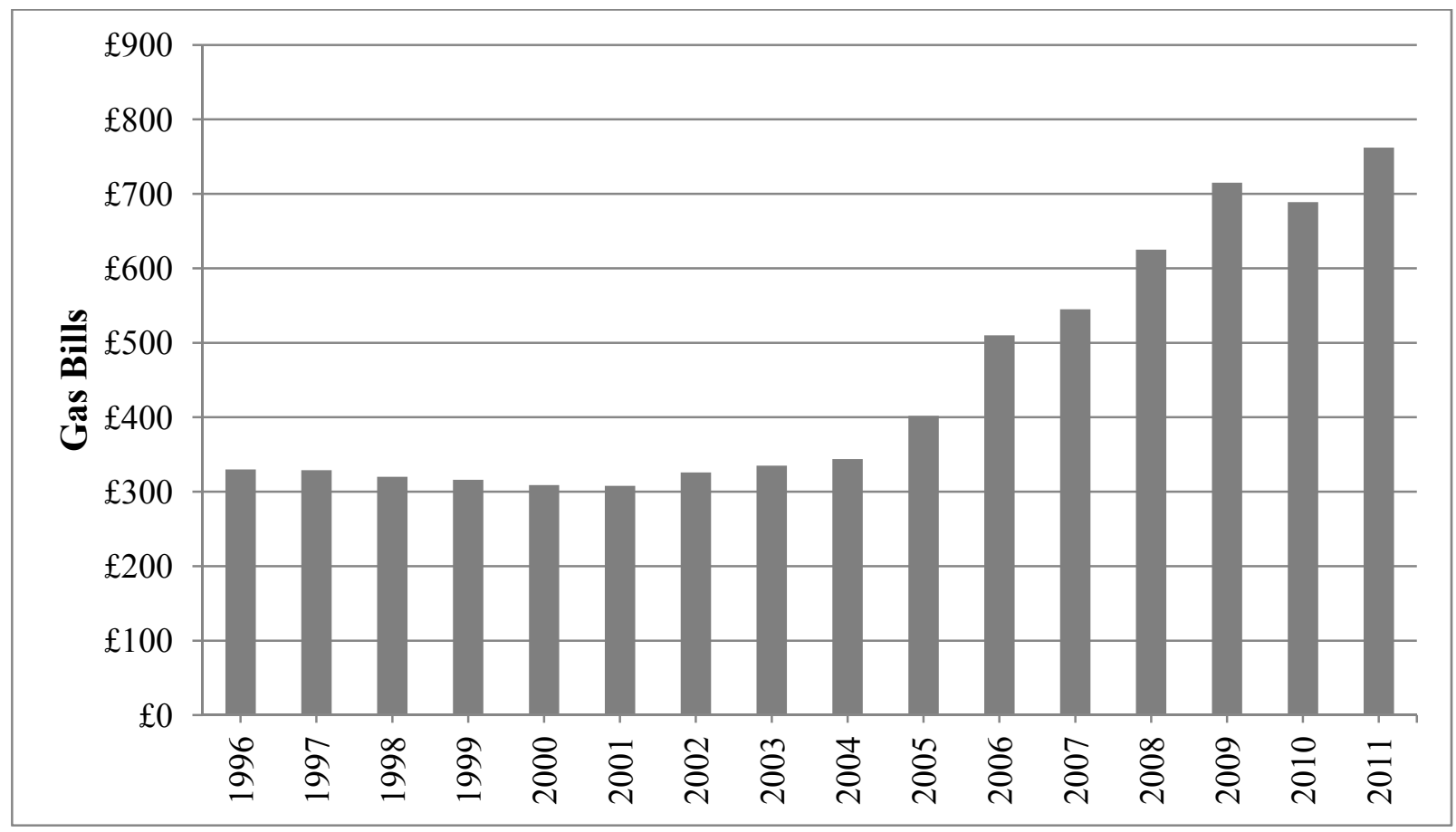

\subsubsection{Standard Deviation and Binomial Tree}

The amount of uncertainty in the future price of a commodity such as gas can be calculated by drawing a binomial tree. In this study, 16 years of gas price datasets were used to adjust the projection 
of future uncertainty, predict future gas prices and find the future outcomes. The instability of a data series is measured by its standard deviation(s), which can be used to indicate the rising and falling values by means of a binomial tree [18]. Drawing a binomial tree (Figure 6) helps to predict the expected future gas prices and related savings. The expected value in each year is the average of all possible outcomes, weighted by their probability.

Figure 6. Binomial tree.

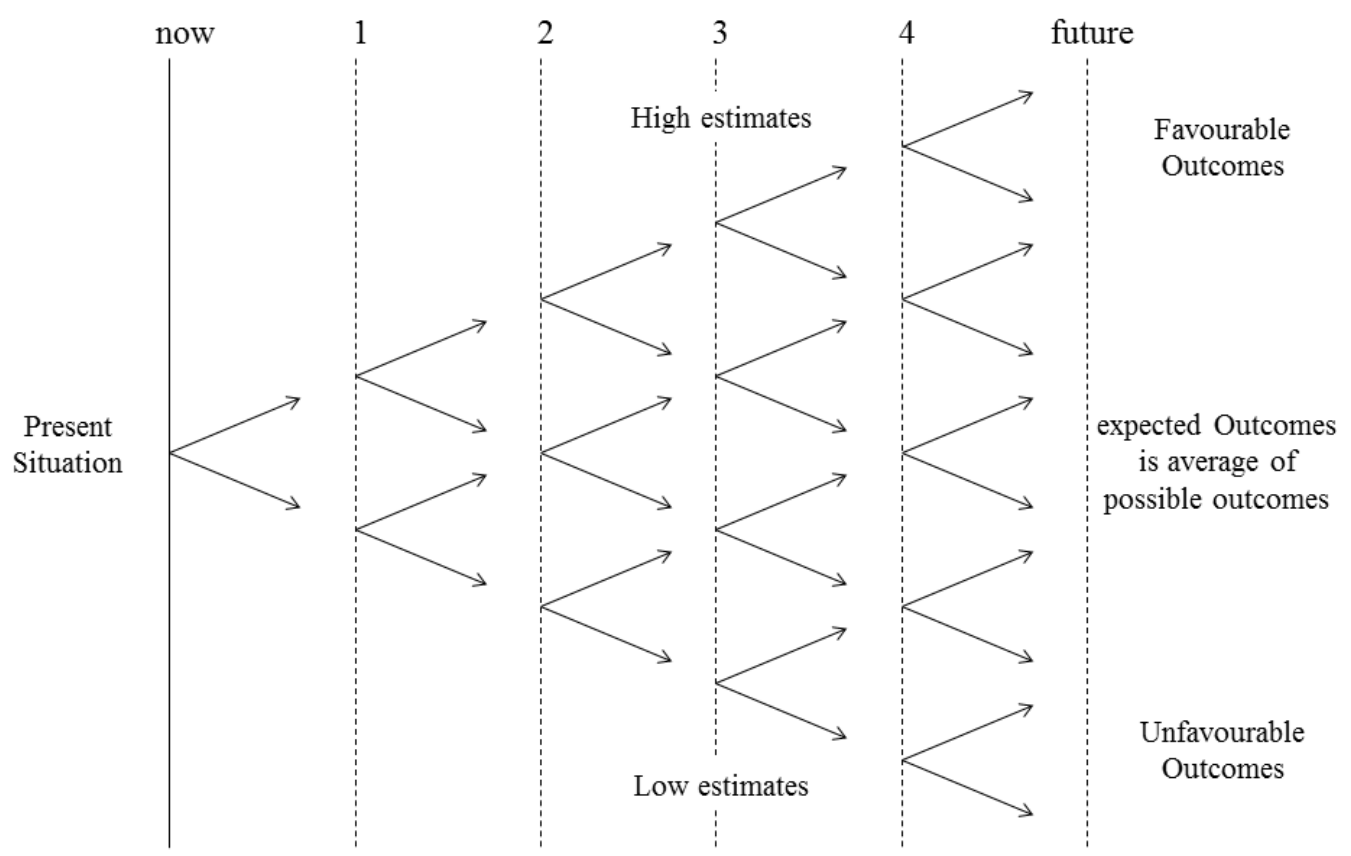

\subsubsection{Time Preference, Discount Rate and Net Present Value}

The discount rate $r$ is the rate at which future expenditures are discounted to establish their present value. It is defined as the value society attaches to present, as opposed to future, consumption [20]. This rate is needed to put the costs of paying future liabilities in to present-day terms, a parameter called the net present value (NPV) [18]. A discount rate of 3.5\% has been chosen as this is used by the UK Government for economic decision making. Inflation has not been taken into account in this research [21]. Applying this 3.5\% discount rate to the savings enabled the NPV of the savings to be calculated. If all the expenditures and incomes in a cash flow (v0, v1, v2, ., vn) are discounted to their present values using the chosen discount rate and then summed, the result is the net present value of the cash flow and will be given by [18]:

$$
N P V=v_{0}+\frac{v_{1}}{(1+r)}+\frac{v_{2}}{(1+r)^{2}}+\cdots \frac{v_{n}}{(1+r)^{n}}
$$

\subsubsection{Payback Period}

The payback period is calculated by deducting the fuel cost saved each year from the capital cost of the energy saving measures. 


\section{Results and Discussion}

\subsection{Effect of the Terraced House's Eco-Refurbishment on Heating Consumption and $\mathrm{CO}_{2}$ Emissions for Current and Future Weather Conditions}

Pre and post-refurbished houses in different cities under current and future weather condition and different scenarios were simulated to see if the UK's $80 \%$ carbon reduction target was achievable by refurbishment. Simulation results given in Figure 7 show the annual heating demand for the pre and post-refurbished houses in different cities and different scenarios. Significant heating demand reductions can be seen after refurbishment in all four cities. Figure 7 also confirms that, despite the fact that heating energy consumptions are affected by climate change, there is very little decline in future heating demand for the house with no refurbishment, while the eco-refurbished dwelling shows a sharp reduction of more than $70 \%$ in energy demand.

Changes of $\mathrm{CO}_{2}$ emissions in London, Liverpool, Manchester and Edinburgh for pre and post-refurbished house are shown in Figure 8. It can be seen that there is a large reduction of around $83 \%$ for the house when located in Liverpool and London and $80 \%$ reduction in $\mathrm{CO}_{2}$ emissions for the house in Manchester and Edinburgh following refurbishment. $\mathrm{CO}_{2}$ emissions are affected by climate change and show a slight downward trend for the house with no refurbishment, but the eco-refurbished dwellings show sharp reduction in $\mathrm{CO}_{2}$ emissions.

Figure 7. Annual heating demand for the pre and post-refurbished terrace house in different cities for current and future weather data.

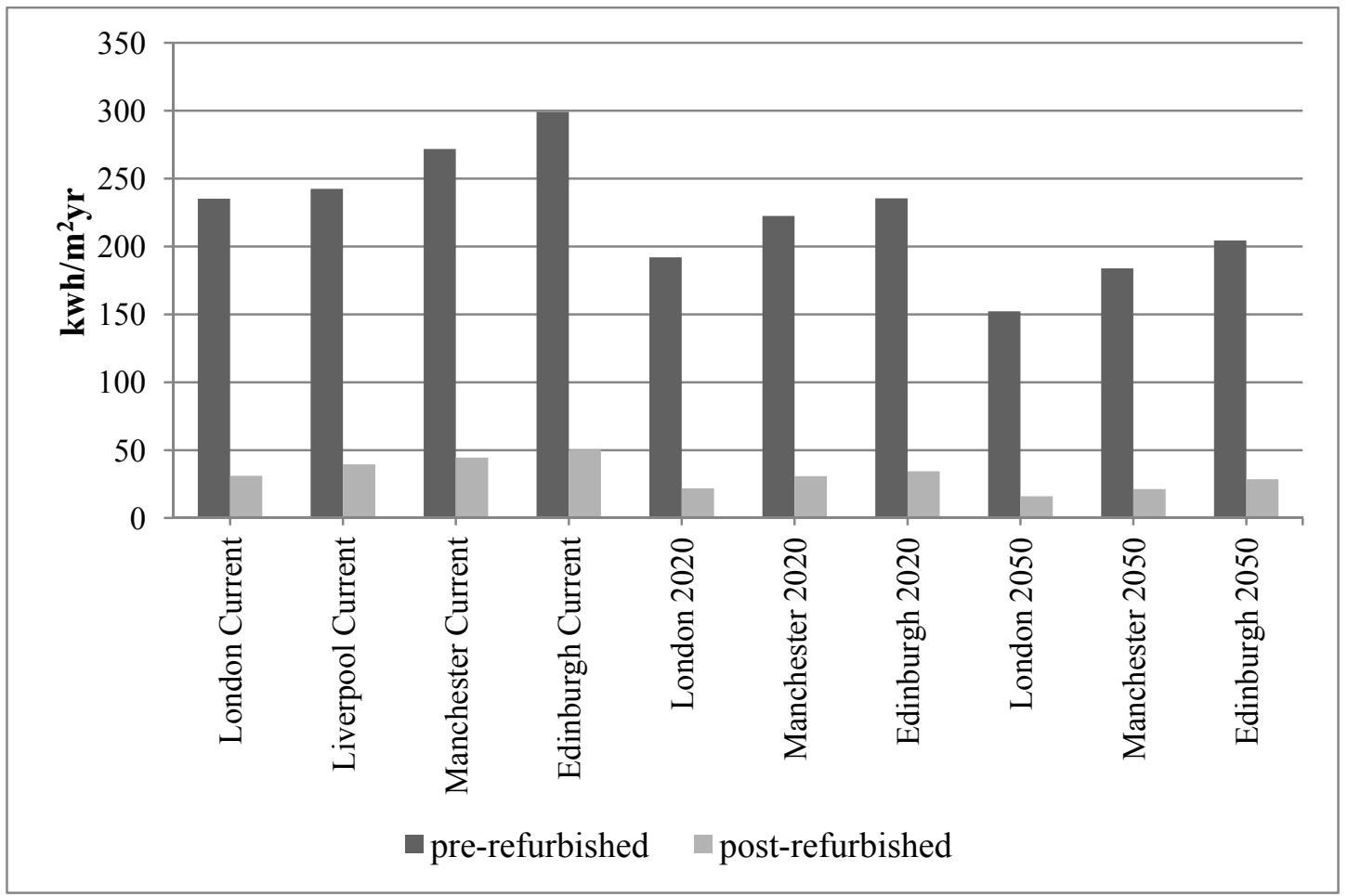


Figure 8. Annual $\mathrm{CO}_{2}$ emissions $\left(\mathrm{kgCO}_{2} / \mathrm{m}^{2} \mathrm{yr}\right)$ from pre and post-refurbished house in different cities under current and future weather conditions.

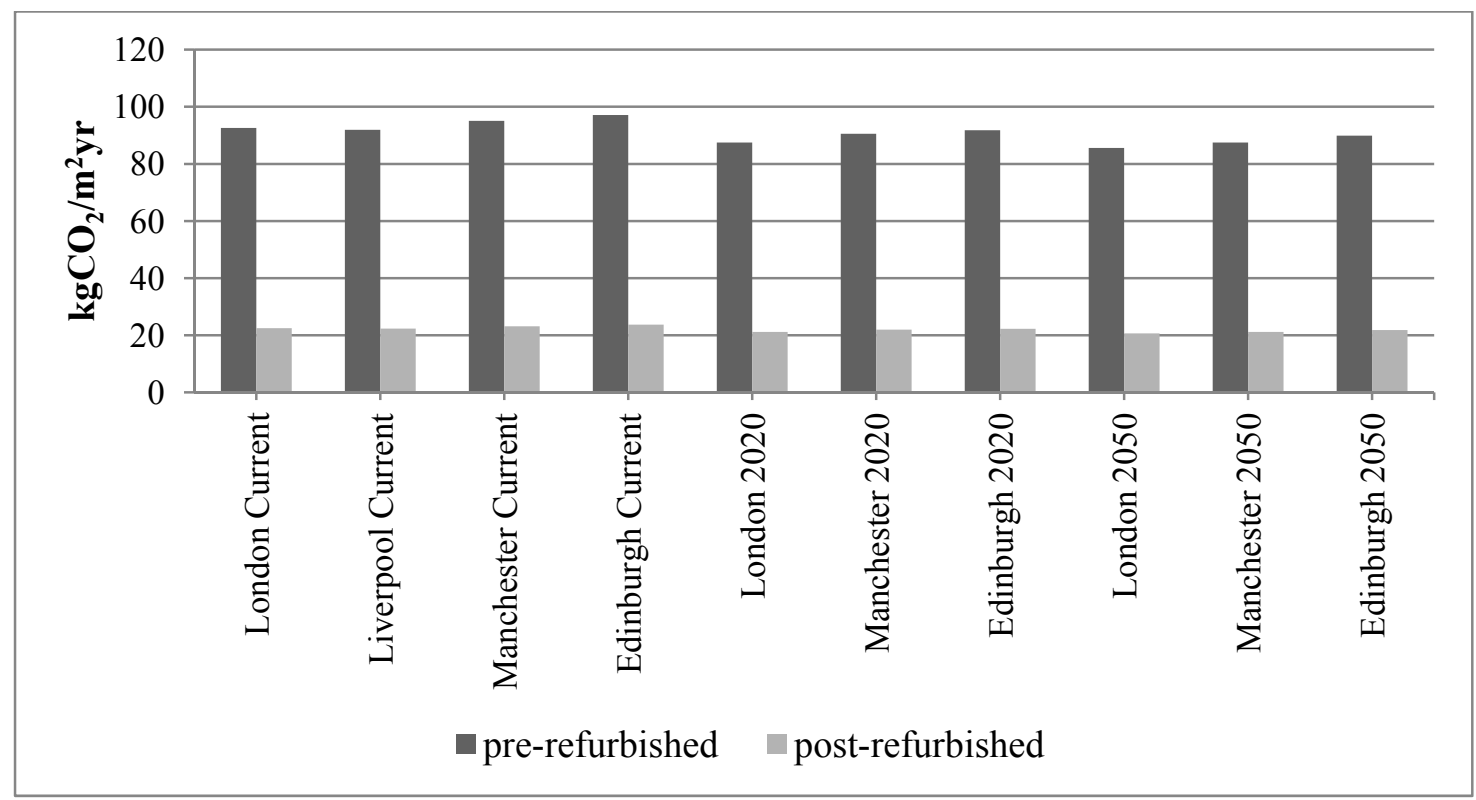

\subsection{Summer and Winter Discomfort Hours}

Figure 9 compares the operative temperature (the average of the internal air and mean radiant temperatures) of the post and pre refurbished house with natural ventilation. It can be concluded from the results that during the summer months the mean peak operative temperature may exceed $25{ }^{\circ} \mathrm{C}$ after refurbishment and so there could be a risk of thermal discomfort if no adaptive measures were taken. However, for most of the year the refurbishment is greatly enhancing thermal comfort in the house. There is a suggestion from Figure 9 that some take-back could occur in the refurbished house i.e., occupants enjoying a higher internal temperature in the heating season than they might have experienced in the pre refurbished house.

Figure 9. Monthly mean operative temperature $\left({ }^{\circ} \mathrm{C}\right)$ from pre and post-refurbished house under current weather conditions (Liverpool).

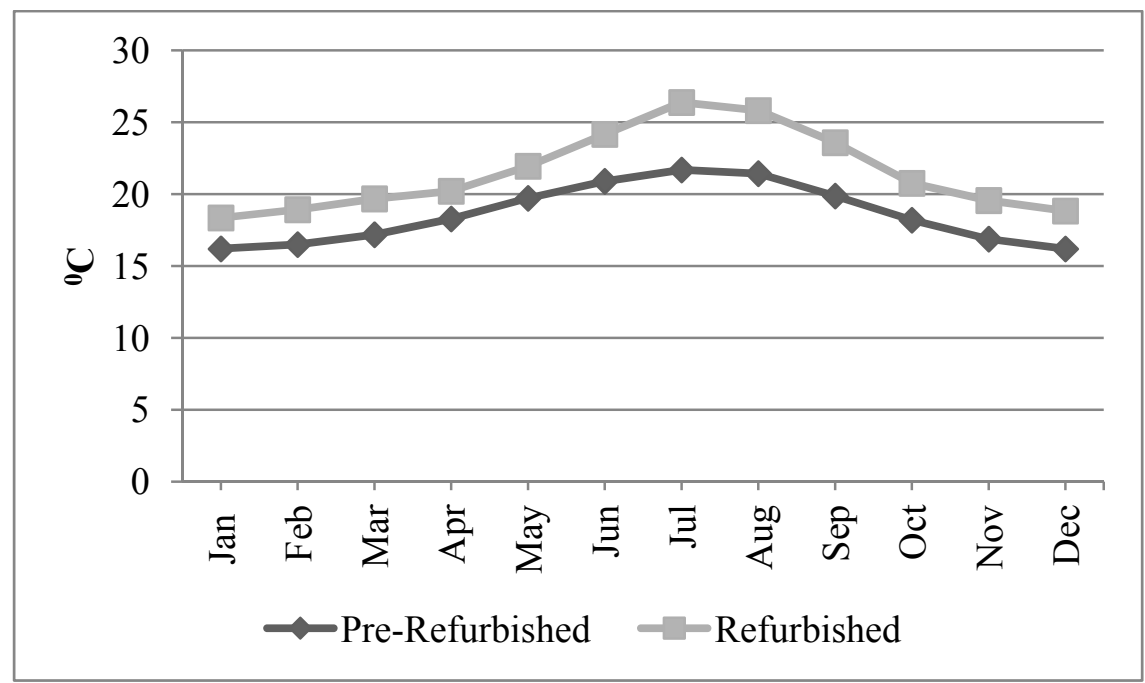




\subsection{Efficiency of Various Technologies in Reducing Carbon Emission and Costs in the Terraced House}

Although results indicate that an $80 \%$ reduction in $\mathrm{CO}_{2}$ emissions is achievable by refurbishment, it is important to consider the time and costs required to reach that target. Figure 10 illustrates typical heat losses from each major construction element in the terraced house, with the main sources of heat loss being the walls and loft. Consequently, improving wall and loft insulation levels can be the most effective way of improving the energy performance of buildings. Therefore, it would useful to also look at the economic performance of these components. Figure 11 indicates the cost of applying each technology.

Figure 10. Typical heat losses from pre and post refurbished building envelope components of the terraced house, showing \% reduction.

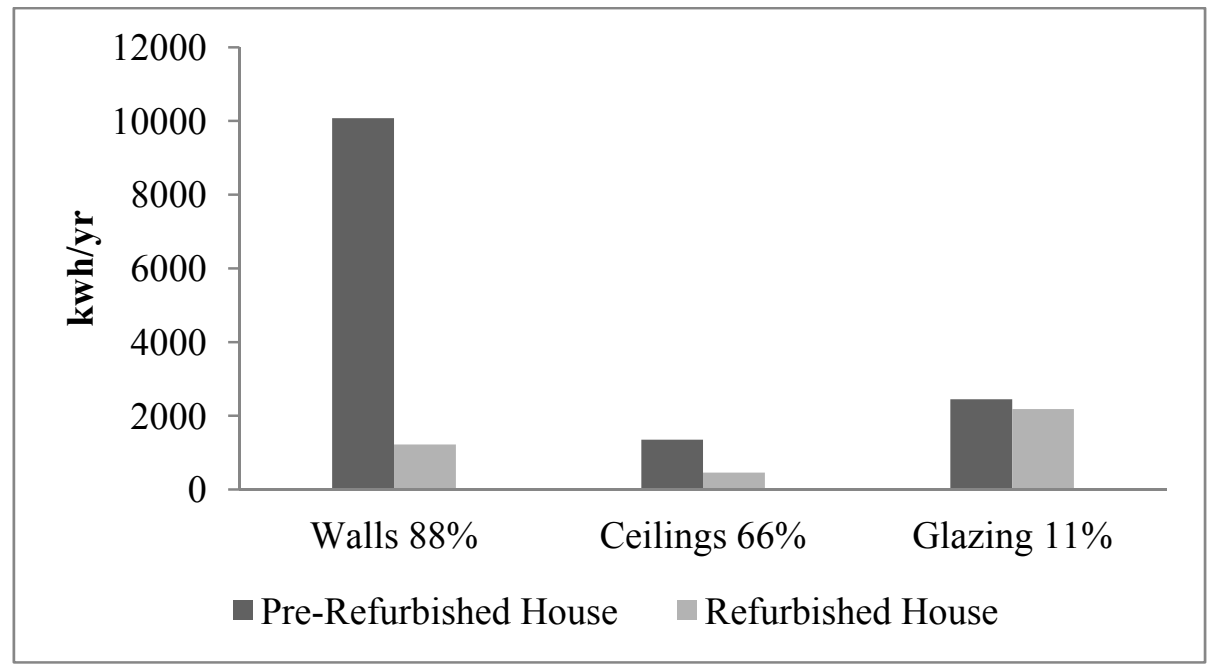

Figure 11. Cost of various low carbon technologies for the terraced house.

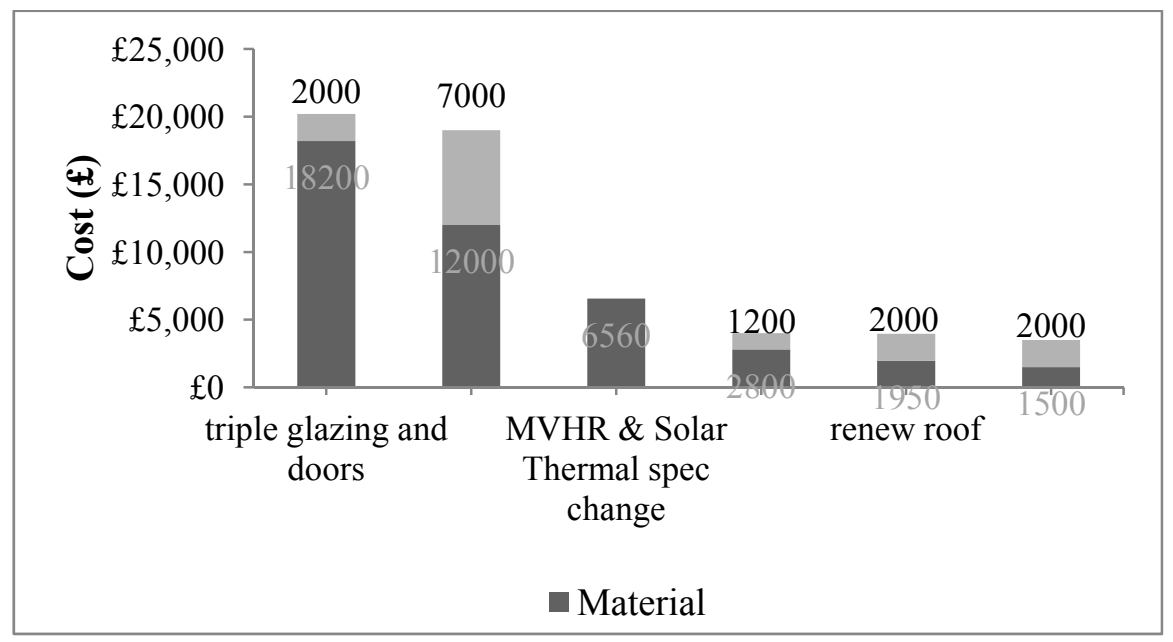

\subsection{Annual Savings for the Terraced House, Liverpool}

Energy savings cost is the difference between DesignBuilder simulation results for the heating consumption of the existing house and the retrofit house. Table 7 illustrates the average internal 
temperature of the living room during the heating season (December, January, February) as modeled by DesignBuilder(DB) for pre and post refurbished house compared to monitoring results.

Table 7. Average internal temperature of living room during the heating season-Liverpool current weather data.

\begin{tabular}{ccc}
\hline & Measures & Operative temperature ${ }^{\circ} \mathbf{C}$ \\
\cline { 2 - 3 } Average internal temperature & DB Pre-Refurbished & 16.3 \\
& DB Refurbished & 19.6 \\
& Monitoring & 25.4 \\
\hline
\end{tabular}

As gas is the primary energy source for heating in this case study, the energy cost is calculated by use of a mean gas price of $0.0475 £ / \mathrm{kWh}$. The annual benefit (the financial saving) is calculated by multiplying energy saving by current gas price of $0.0475 £ / \mathrm{kWh}$ for the first year in the cash flow. The numerical results for different cities are listed in Table 8.

Table 8. Annual savings from lower gas consumption for heating - current weather data.

\begin{tabular}{ccccc}
\hline Climate scenarios & $\begin{array}{c}\text { Estimated annual } \\
\text { heating load for } \\
\text { existing house } \\
\mathbf{( k W h )}\end{array}$ & $\begin{array}{c}\text { Estimated annual } \\
\text { heating load for } \\
\text { refurbished house } \\
\mathbf{( k W h )}\end{array}$ & $\begin{array}{c}\text { Heating } \\
\text { reduction (kWh) }\end{array}$ & $\begin{array}{c}\text { Annual energy } \\
\text { cost savings (f) for } \\
\text { a gas price of } \\
\mathbf{0 . 0 4 7 5} \mathfrak{f} / \mathbf{k W h}\end{array}$ \\
\hline London-Current & 12,336 & 2527 & 9808 & 466 \\
Liverpool-Current & 12,628 & 2587 & 10,041 & 477 \\
Manchester-Current & 13,500 & 2878 & 10,622 & 505 \\
Edinburgh-Current & 15,200 & 3114 & 12,086 & 574 \\
\hline
\end{tabular}

To calculate the future annual savings three factors must be considered: effect of climate change on annual savings, instability of future gas prices and time preference and discount rate.

\subsection{Future Climate Change and Annual Savings}

Climate change affects heating consumption and accordingly the annual energy savings. Table 9 shows the reduction of heating consumption for different climate scenarios and different cities.

Table 9. Annual energy savings for future climate scenarios.

\begin{tabular}{cccc}
\hline Climate scenarios & $\begin{array}{c}\text { Estimated annual heating load } \\
\text { for existing house } \mathbf{( k W h )}\end{array}$ & $\begin{array}{c}\text { Estimated annual heating load } \\
\text { for refurbished house (kWh) }\end{array}$ & $\begin{array}{c}\text { Reduction } \\
(\mathbf{k W h}) \mathbf{( \% )}\end{array}$ \\
\hline London 2020 & 11,419 & 1908 & $9511(83 \%)$ \\
Edinburgh 2020 & 12,188 & 2497 & $9691(80 \%)$ \\
Manchester 2020 & 10,675 & 2168 & $8507(80 \%)$ \\
London 2050 & 8148 & 1669 & $6479(80 \%)$ \\
Edinburgh 2050 & 10,762 & 2205 & $8557(80 \%)$ \\
Manchester 2050 & 9483 & 1833 & $7650(81 \%)$ \\
\hline
\end{tabular}




\subsection{Future Gas Prices and Annual Savings}

As any cost benefit analysis is performed over the lifetime of a house, a changing rate has to be introduced in the cost calculations to correspond with reality. Looking at historical data suggests that not only will energy prices not remain constant but that there is also a possibility of both downward and upward trends as well. Therefore, different scenarios should be investigated that take in to account different trends. To measure the amount of uncertainty and to predict gas price trends 16 years of gas price datasets were used and the change over time (standard deviation) was calculated (Table 10). The instability of the annual variation was calculated in this case to be $8.6 \%$ (see Equation 3 ).

Table 10. Average annual standard credit bills $(£)$ for a typical residential gas consumer for 16 years since 1996 source [19].

\begin{tabular}{|c|c|c|c|}
\hline Year & Gas prices in real terms $(\mathfrak{f})$ & Annual \% variation & Instability \\
\hline 1996 & 330 & - & - \\
\hline 1997 & 329 & -0.3 & -6.3 \\
\hline 1998 & 320 & -2.7 & -8.8 \\
\hline 1999 & 316 & -1.2 & -7.3 \\
\hline 2000 & 309 & -2.2 & -8.3 \\
\hline 2001 & 308 & -0.3 & -6.4 \\
\hline 2002 & 326 & 5.8 & -0.2 \\
\hline 2003 & 335 & 2.7 & -3.3 \\
\hline 2004 & 344 & 2.6 & -3.4 \\
\hline 2005 & 402 & 16.8 & 10.8 \\
\hline 2006 & 510 & 26.8 & 20.8 \\
\hline 2007 & 545 & 6.8 & 0.8 \\
\hline 2008 & 625 & 14.6 & 8.7 \\
\hline 2009 & 715 & 14.4 & 8.3 \\
\hline 2010 & 689 & -3.6 & -9.7 \\
\hline 2011 & 762 & 10.6 & 4.5 \\
\hline Average & - & 6.07 & - \\
\hline \multicolumn{4}{|c|}{$\frac{(-6.3)^{2}+(-8.8)^{2}+(-7.3)^{2}+\cdots(4.5)^{2}}{(16-1)}$} \\
\hline
\end{tabular}

Finding the ratio that controls the rising and falling values allows a binomial tree of gas price trends to be constructed for the next 16 years. To predict the gas prices for year 16-40 the standard deviation was calculated again using years 1 to 16 predicted gas prices and was found to be $23 \%$.

Figure 12 illustrates the predicted different possible gas prices in each year. The expected gas price in each year is the sum of all possibilities weighted by their probabilities. The right vertical axis shows the predicted prices for an upward trend and the left vertical axis illustrates the projected gas prices for a downward and current trend. After each 16 years, the previous 16 years of data were used to predict the new gas prices. For a better comparison, a different scale has been chosen on the right hand side for the upward trend. Expected gas prices in the next 40 years can be seen in Table 11. 
Figure 12. Predicted possible Index upwards or downwards prices for gas.

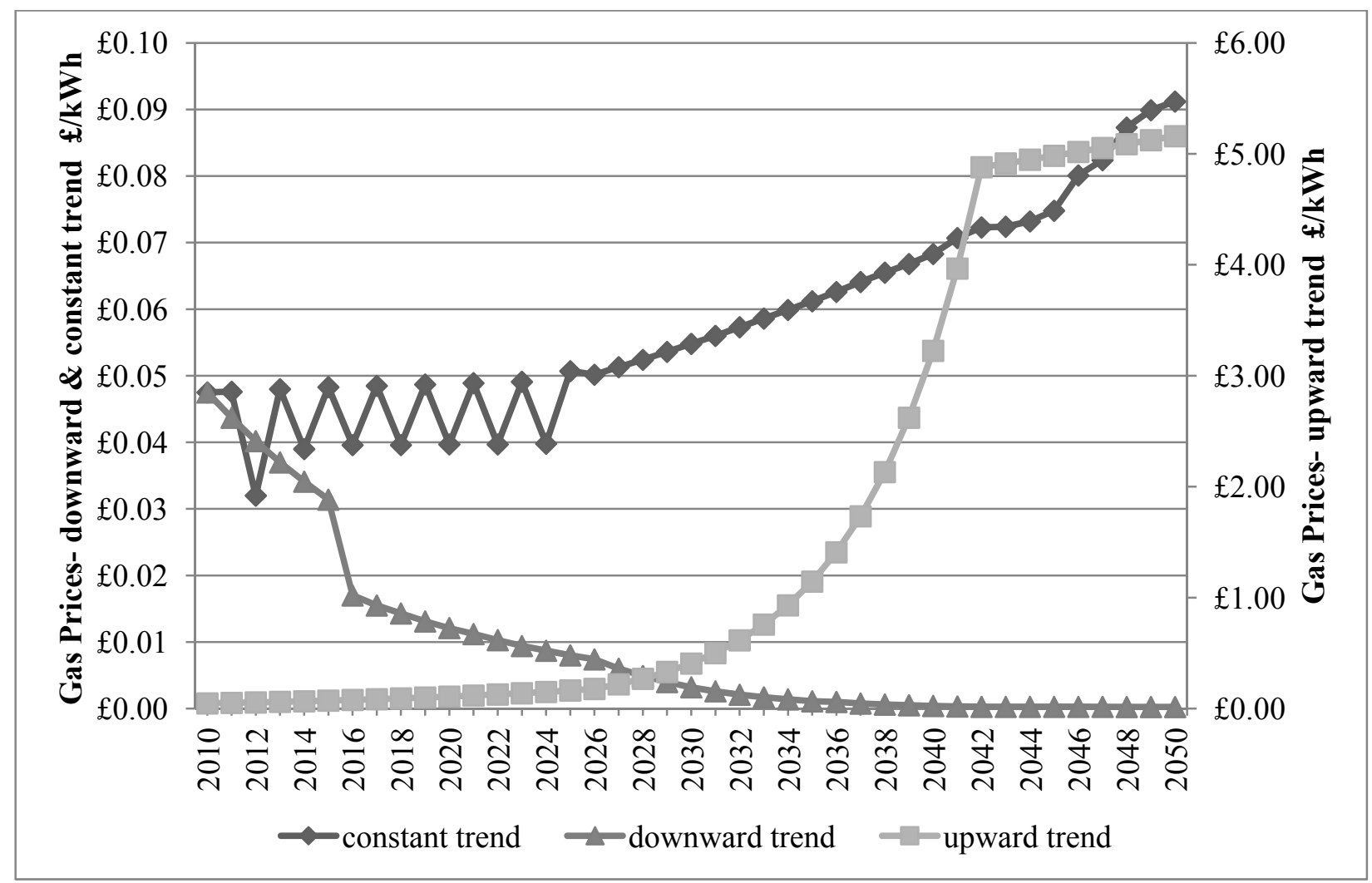

Table 11. Future energy saving costs for constant prices in London for 2010-2020.

\begin{tabular}{|c|c|c|c|c|c|c|c|}
\hline year & $\begin{array}{l}\text { Refurbished } \\
\text { annual } \\
\text { heating load } \\
(\mathrm{kWh})\end{array}$ & $\begin{array}{c}\text { Existing } \\
\text { annual } \\
\text { heating load } \\
(\mathbf{k W h})\end{array}$ & $\begin{array}{c}\text { Gas } \\
\text { prices } \\
(\mathbf{p} / \mathbf{k W h})\end{array}$ & $\begin{array}{l}\text { Refurbished } \\
\text { annual } \\
\text { heating cost } \\
\text { (f) }\end{array}$ & $\begin{array}{c}\text { Existing } \\
\text { annual } \\
\text { heating } \\
\text { cost }(\mathfrak{f})\end{array}$ & $\begin{array}{c}\text { Annual } \\
\text { savings } \\
\text { (f) }\end{array}$ & $\begin{array}{c}\text { Annual } \\
\text { savings, } \\
\text { NPV at } \\
3.5 \% / 3 \% \\
\text { discount }\end{array}$ \\
\hline 2010 & 2527 & 12336 & 4.75 & 120.03 & 585.94 & 465.91 & 465.91 \\
\hline 2011 & 2458 & 12236 & 4.76 & 117.01 & 582.33 & 465.32 & 449.58 \\
\hline 2012 & 2389 & 12132 & 3.20 & 76.46 & 388.22 & 311.76 & 291.03 \\
\hline 2013 & 2321 & 12030 & 4.80 & 111.40 & 577.45 & 466.05 & 420.35 \\
\hline 2014 & 2252 & 11928 & 3.90 & 87.83 & 465.21 & 377.37 & 328.86 \\
\hline 2015 & 2183 & 11827 & 4.83 & 105.46 & 571.23 & 465.76 & 392.16 \\
\hline 2016 & 2115 & 11725 & 3.96 & 83.74 & 464.30 & 380.56 & 309.58 \\
\hline 2017 & 2046 & 11623 & 4.85 & 99.23 & 563.72 & 464.48 & 365.08 \\
\hline 2018 & 1977 & 11521 & 3.96 & 78.30 & 456.24 & 377.94 & 287.01 \\
\hline 2019 & 1909 & 11419 & 4.87 & 92.95 & 556.12 & 463.17 & 339.84 \\
\hline 2020 & 1908 & 11419 & 3.97 & 75.74 & 453.33 & 377.58 & 267.68 \\
\hline
\end{tabular}

\subsection{Future Energy Saving Costs}

Estimating future gas prices makes it possible to calculate savings for the building's energy expenditure. As these savings happen for different operations taking place at different times, it is essential to convert to current costs using a discounted cash flow method that incorporates the discount 
rate of $3.5 \%$ for the first 30 years and 3\% thereafter (Table 11 shows the values for London for the period 2010-2020).

\subsection{Whole Life Cycle Costing}

Discounted accumulated whole life cycle costs over 40 years for three gas prices and three weather scenarios are shown in Figures 13-15 for the terraced house located in London, Manchester and Edinburgh. A comparison of WLCC for all cities shows that this type of refurbishment is economically attractive only with the rising gas prices scenario. Clearly, adding the maintenance and replacement costs to the analysis will change these findings dramatically in favor of the refurbished house's WLCC.

Comparing the most favorable outcomes (with upward prices) for all three cities it can be seen in Figure 16 that the total present value for Edinburgh is the most beneficial option over 40 years (£ 178,752 savings), before Manchester ( $£$ 154,208 savings) and London ( $£$ 138,090 savings), for the given conditions ( $3 \%$ discount rate, $8.6 \%$ yearly increase in energy costs for the first 16 years and $23 \%$ increase in energy costs after that).

Figure 13. Whole Life Cycle Cost (WLCC) of the pre and post refurbished house for current and future London weather data over 40 years for different gas price trends.

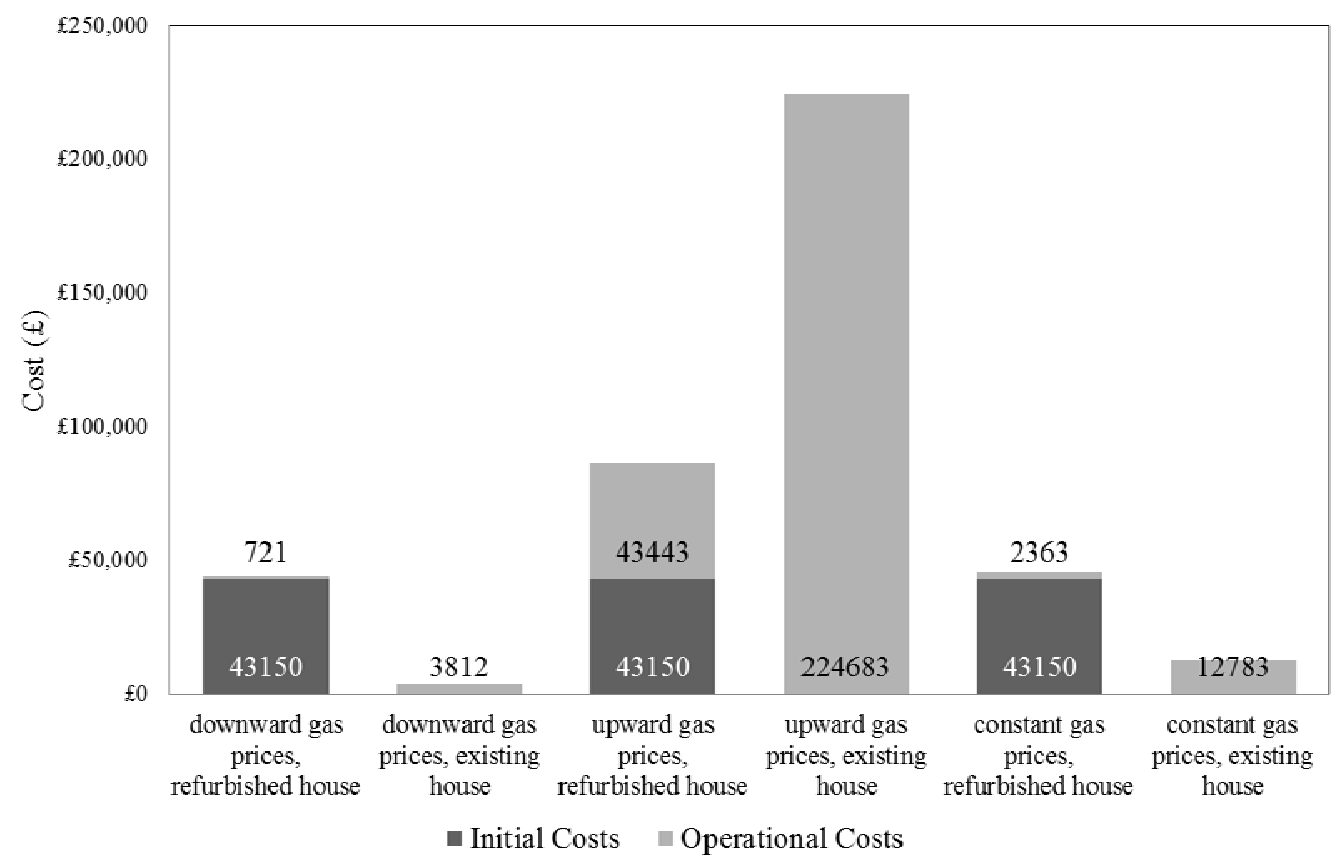


Figure 14. Whole Life Cycle Cost (WLCC) of the post and pre refurbished house for current and future Manchester weather data over 40 years for different gas price trends.

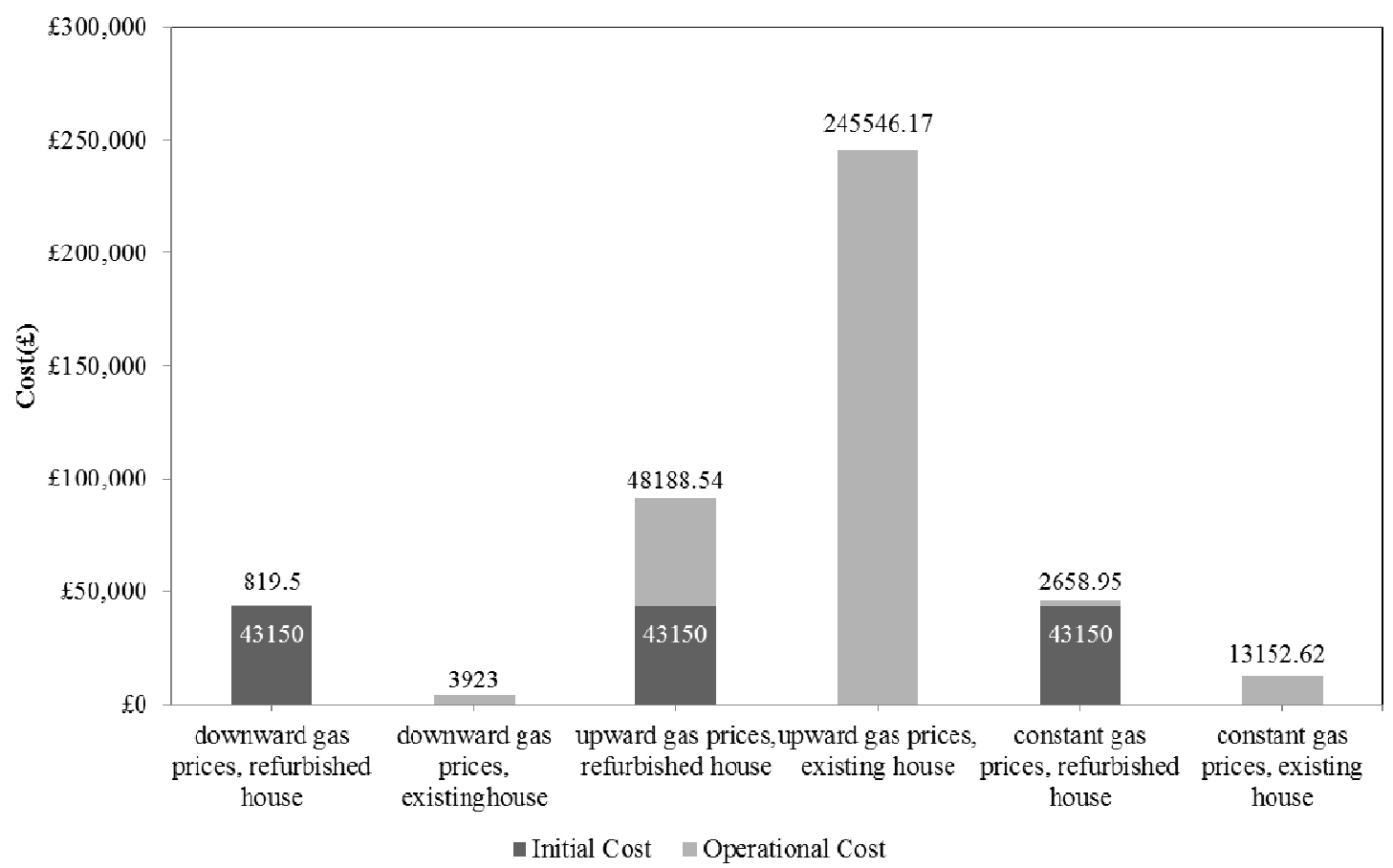

Figure 15. Whole Life Cycle Cost (WLCC) of the post and pre refurbished house for current and future Edinburgh weather data over 40 years for different gas price trends.

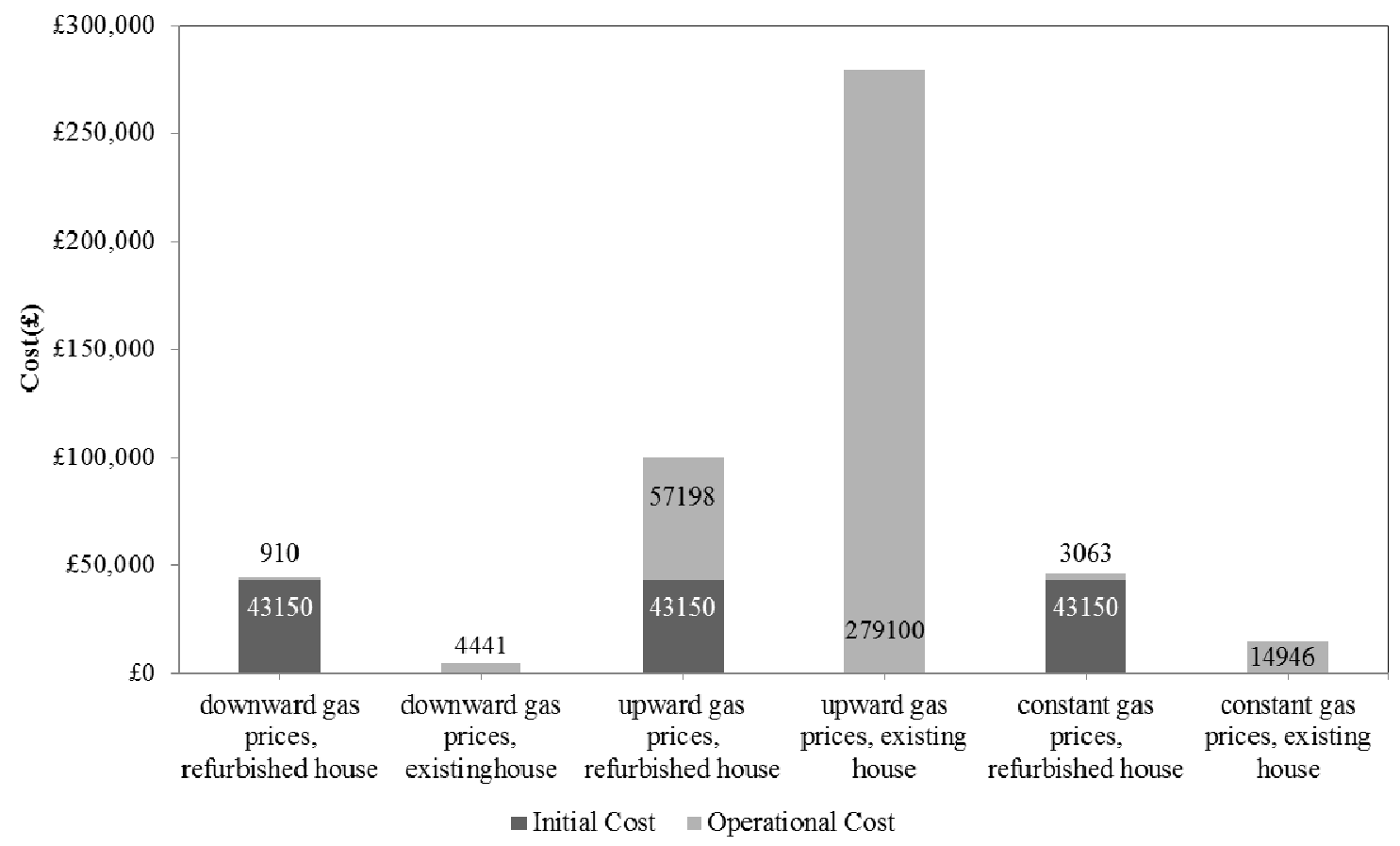


Figure 16. Whole Life Cycle Cost (WLCC) of the post and pre refurbished house for current and future weather data of London, Edinburgh and Manchester over 40 years for upward gas price trends.

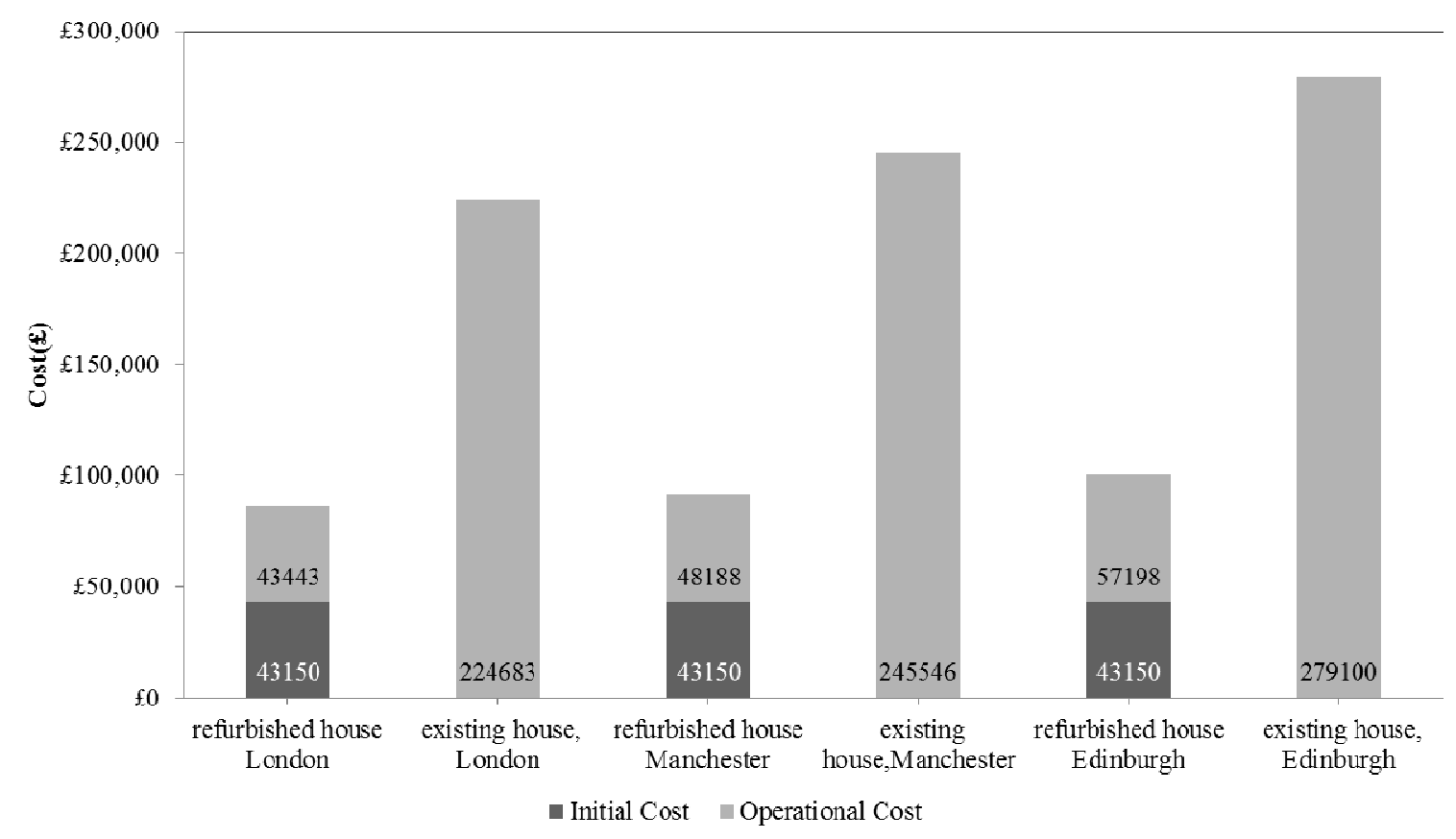

\subsection{Payback Period}

\subsubsection{London}

Figure 17 showing the time needed to recover the initial costs of eco-refurbishment with constant, growing and decreasing energy prices. The figure of $-£ 43,150$ shows the initial cost of construction with the amount of corresponding discounted saving costs added every year. The cumulative cash flow of the refurbished house for various trends shows that the payback time from heating saved by improving wall and roof insulation, glazing and doors to near Passivhaus standards for a 19th century terraced house in London will be 27 years with upward prices and may never realistically pay back if prices fall or remain constant. Figure 18 shows the evolution of the energy costs over 40 years for upward gas prices. If the energy cost grows annually at $8.6 \%$ per year in the first 16 years and at $23 \%$ per year in the second 16 years then after 27 years, the refurbished house will have recovered the cost of the refurbishment. 
Figure 17. Cumulative cash flow of the refurbished house for current and future London weather data over 40 years for different gas price trends.

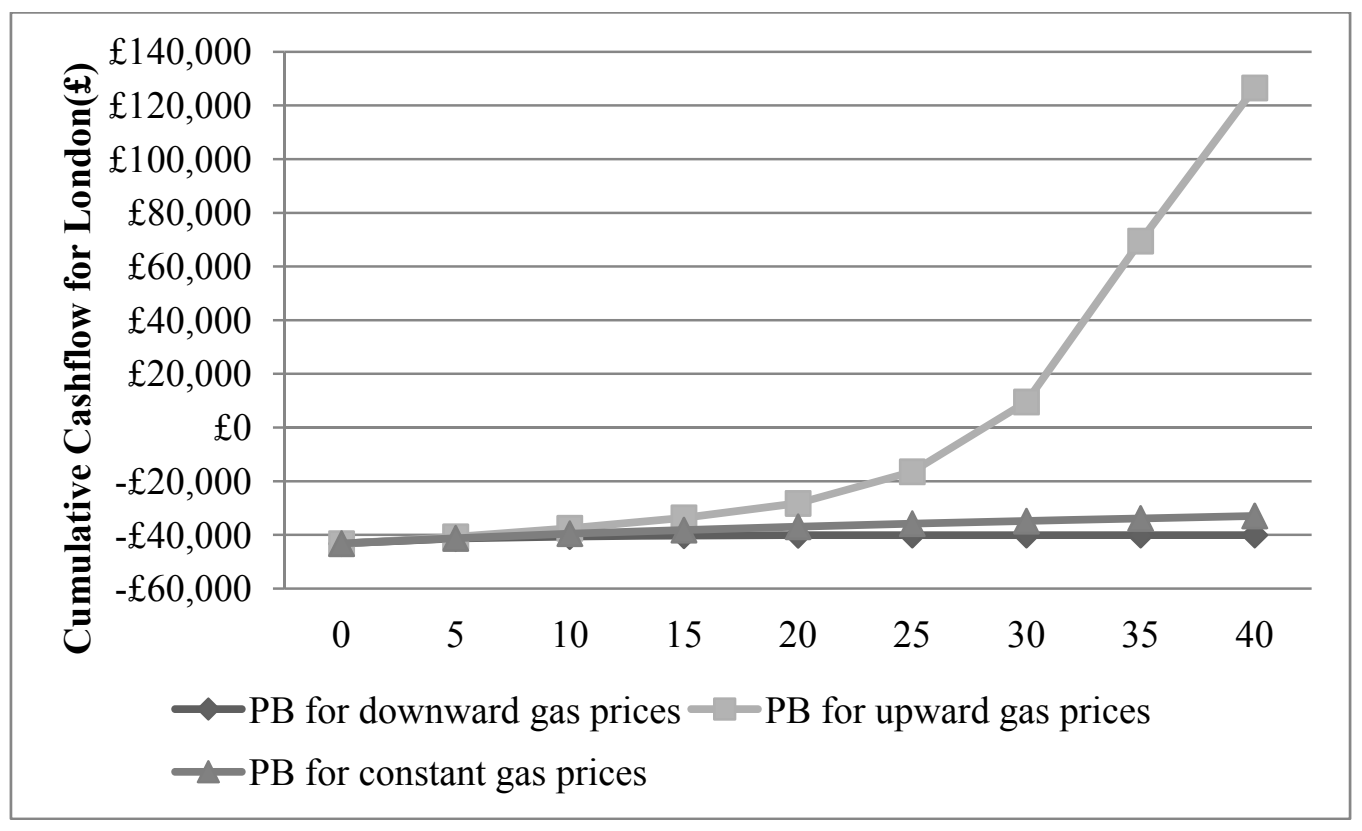

Figure 18. Comparison of the pre and post refurbished house's cumulative discounted operational costs for London current and future weather data over 40 years imposing an upward gas price trend.

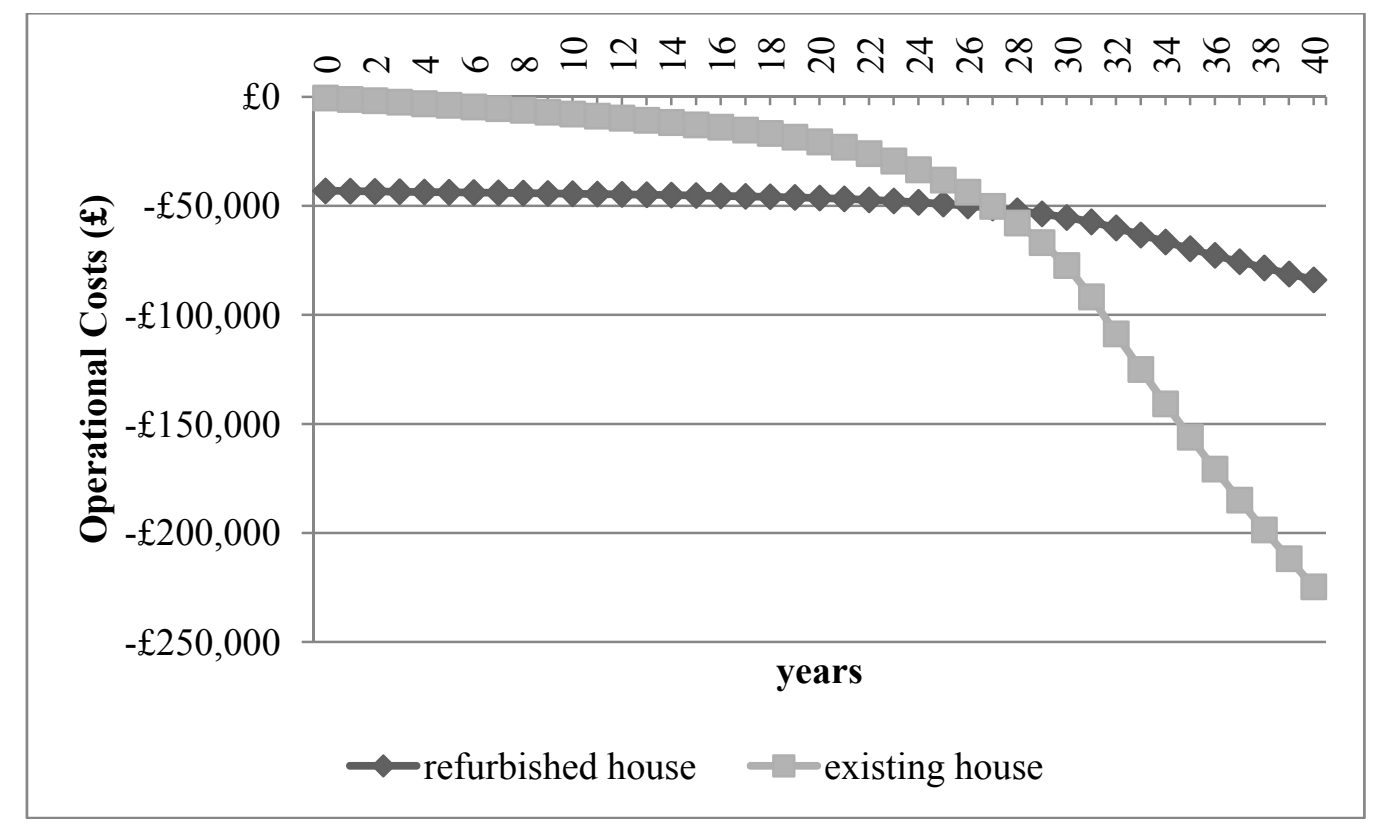

\subsubsection{Manchester}

The same assumptions for gas prices were made to observe the cost benefit of refurbishment in Manchester. It is apparent from Figure 19 that the discounted payback period will be 29 years with upward prices and again, realistically, may never pay back if the prices fall or remain constant. In the case of an increase in energy prices, in year 29 the difference between the non-retrofitted and house will be $£ 1,885.57$ in favor of the refurbished house (see Figure 20). 
Figure 19. Cumulative cash flow of the refurbished house for current and future Manchester weather data over 40 years for different gas price trends.

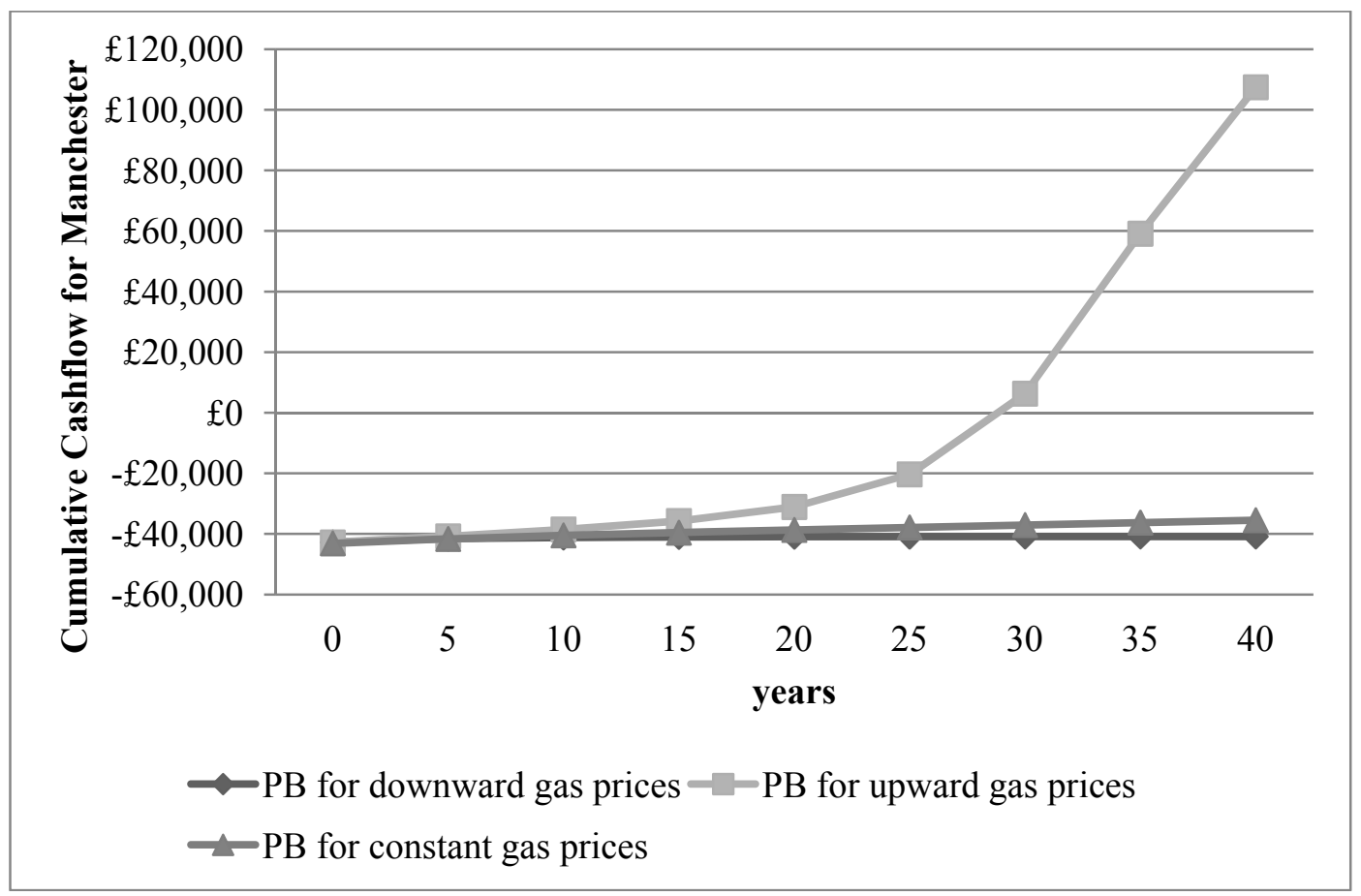

Figure 20. Comparison of the pre and post refurbished house's cumulative discounted operational costs for Manchester current and future weather data over 40 years imposing an upward gas price trend.

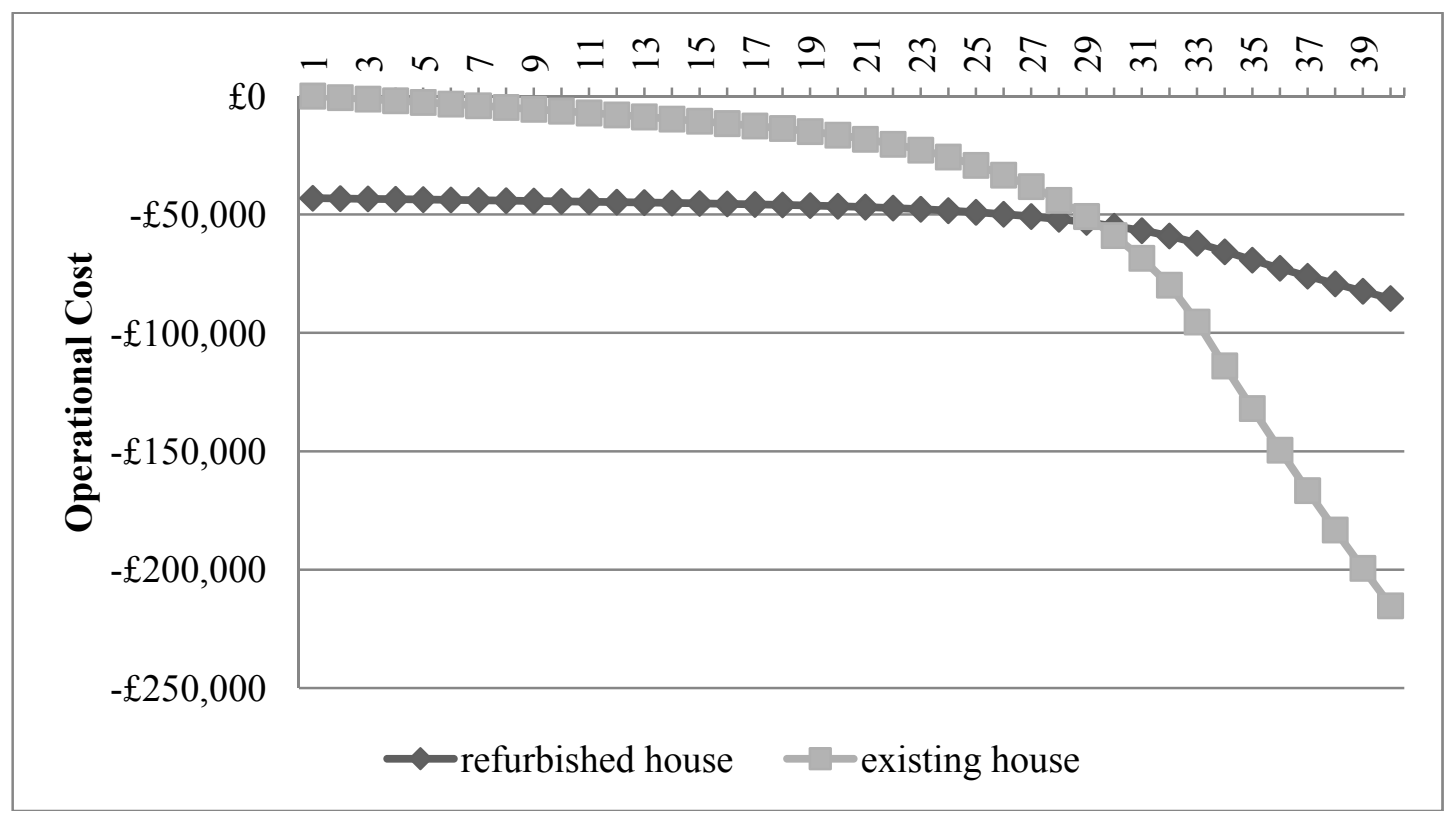

\subsubsection{Edinburgh}

Comparison of net present value cash flow of the refurbished house for different gas price trends for Edinburgh weather data can be seen in Figure 21. Figure 22 shows that for this case the time needed to 
recover the construction cost of refurbishing to near Passivhaus standards is 28 years and, as a result, a positive impact on the annual budget will happen after 28 years.

Figure 21. Cumulative cash flow of the refurbished house for current and future Edinburgh weather data over 40 years for different gas price trends.

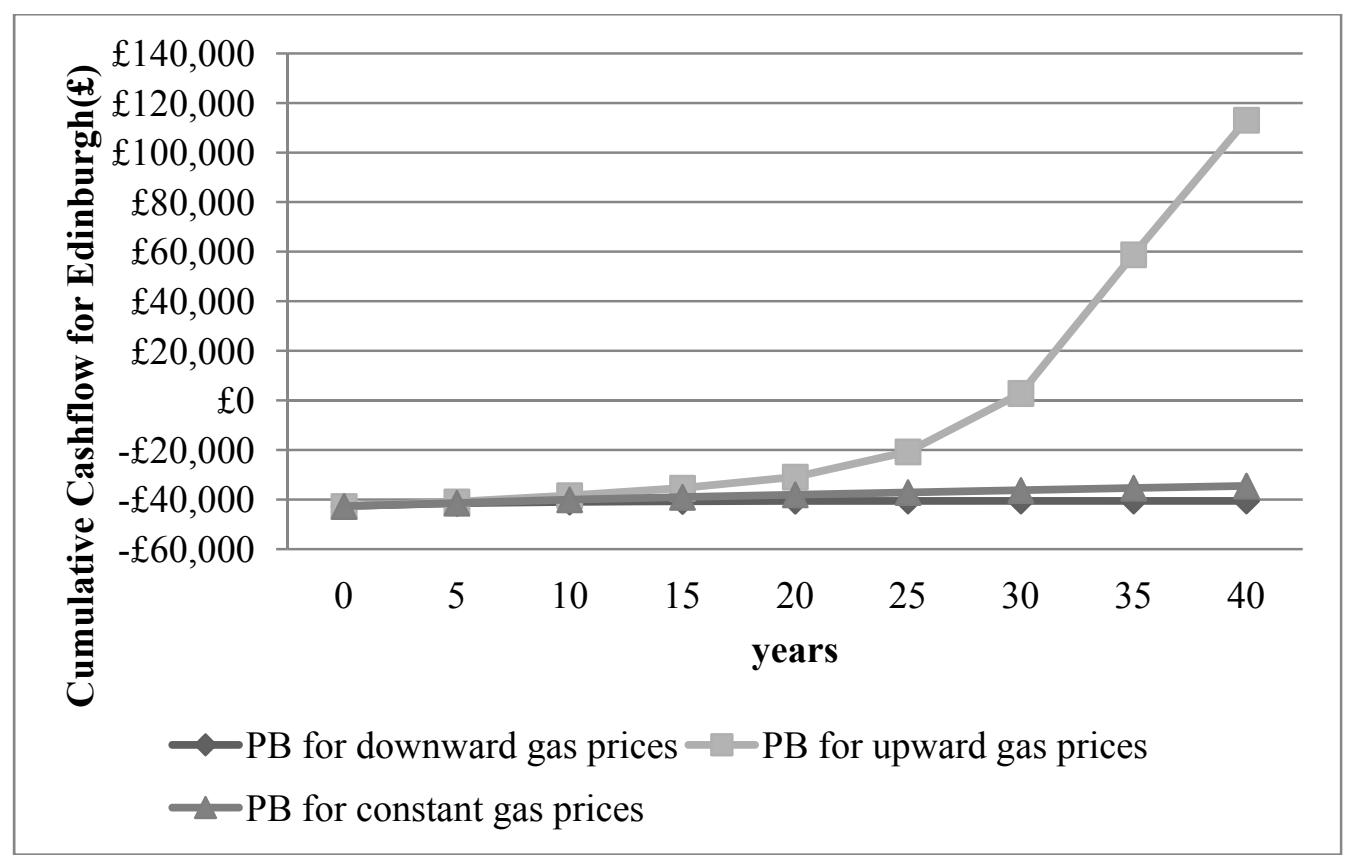

Figure 22. Comparison of the pre and post refurbished house's cumulative discounted operational costs for Edinburgh current and future weather data over 40 years imposing an upward gas price trend.

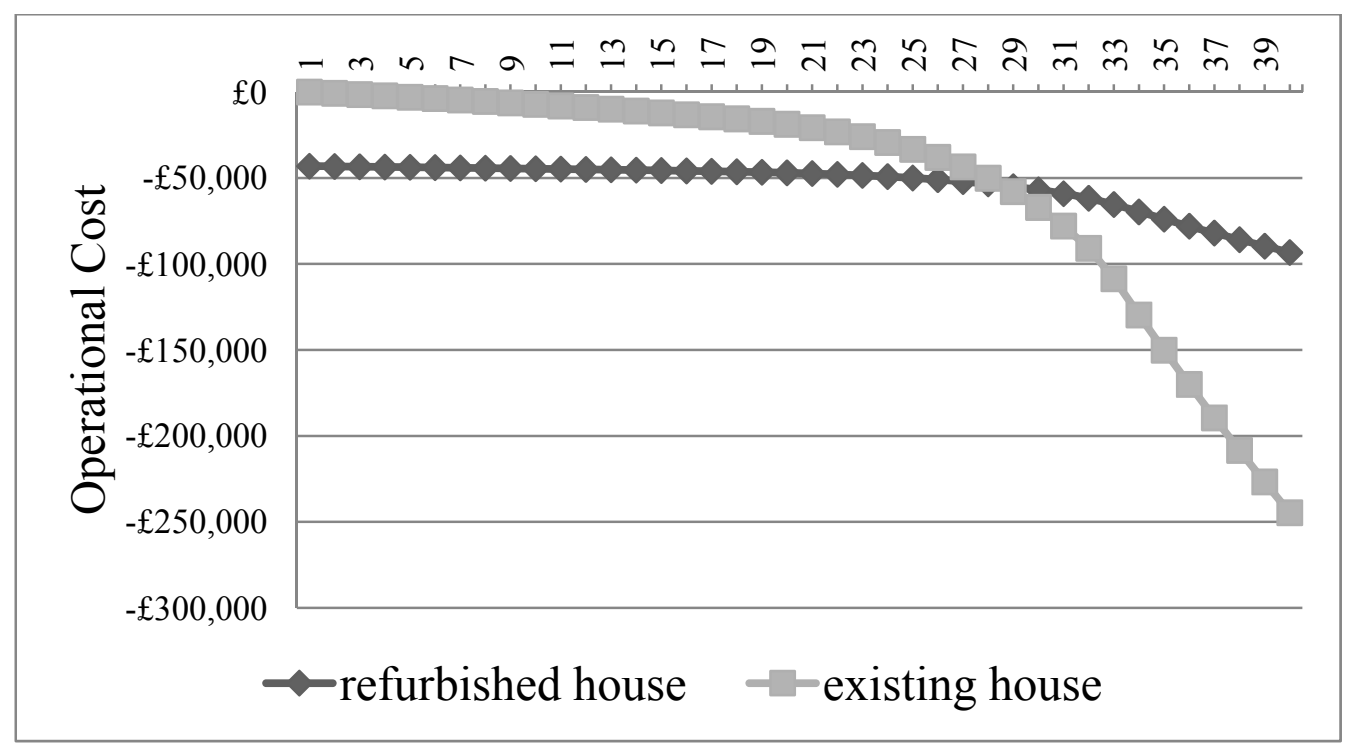

\section{Conclusions}

This analysis of a 19th century terraced house refurbished to near Passivhaus standards has been divided into two stages: first, the energy consumption and $\mathrm{CO}_{2}$ emission were determined and, second, a cost analysis of the construction type (improving the glazing type, wall and loft insulation) was 
undertaken. In the first step, applying all strategies were studied to determine the possibility of reaching an $80 \%$ emissions reduction by eco-refurbishment. Results indicate that energy demands and $\mathrm{CO}_{2}$ emissions experience a sharp decline following eco-refurbishment. Comparing the cost of this type of refurbishment shows that the most efficient measures are also the most costly ones as well. Accordingly, based on the different future gas prices, energy costs were calculated for the house in different cities. From the second stage of this study, it can be concluded that the payback time and WLCC of this type of refurbishment is very dependent on the growth of the energy prices and that energy prices are unpredictable. The most favorable energy bill savings occurred by imposing the rising prices - this gave a payback time of less than 30 years for all cities.

\section{Acknowledgments}

This paper builds on work carried out as part of TSB's Retrofit for the Future programme. Martin Gladwin, project leader at the Plus Dane Group for the terraced house refurbishment, kindly shared his experiences and monitored data, and the authors gratefully acknowledge his support,

\section{Conflict of Interest}

The authors declare no conflict of interest.

\section{References}

1. Building a Greener Britain. Available online: http://www.fmb.org.uk/news/campaigns/building-agreener-britain/ (accessed on 11 November 2012).

2. Department of Energy and Climate Change. Available online: http://www.decc.gov.uk/assets /decc/What\%20we\%20do/A\%20low\%20carbon\%20UK/1358-the-carbon-plan.pdf (accessed on 11 November 2012).

3. PASSIVHAUS. Available online: http://www.passivhaus.org.uk/standard.jsp?id=122 (accessed on 31 October 2012).

4. AECB, Carbon Lite. Available online: http://www.carbonlite.org.uk/carbonlite/passivhaus.php (accessed on 31 October 2012).

5. Trafford Eco House. Available online: http://traffordecohouse.wordpress.com/2009/01/03/apassivhaus-passive-house-renovation/ (accessed on 19 September 2012).

6. Technology Strategy Board. Available online: http://www.innovateuk.org/ourstrategy /innovationplatforms/lowimpactbuilding/retrofit-.ashx (accessed on 11 November 2012).

7. Plus Dane Group. Available online: http://www.plusgroupltd.org.uk/article.asp?id=389 (accessed on 25 September 2012).

8. Bonfield, P. Rising to the refurbishment challenge. Green Build 04 July 2012; Available online at: http://www.environmentmagazine.co.uk/features/green-build/760-rising-to-the-refurbishmentchallenge (accessed on 25 September 2012).

9. Appendix S: Reduced Data SAP for existing dwellings. Available online: http://www.bre.co.uk /filelibrary/accreditation/scheme_standards/SAP_2009_9-91_Appendix_S_January_2012.pdf (accessed on 18 December 2012). 
10. Low Energy Building Database. Available online: http://retrofitforthefuture.org/project PDF.php?id=77 (accessed on 18 December 2012).

11. IPCC (Intergovernmental Panel on Climate Change). The Physical Science Basis: Contribution of Working Group I 2007; Cambridge University Press: Cambridge, UK, 2007.

12. University of Southampton, Sustainable Energy Research Group. Available online: http://www.serg.soton.ac.uk/ccweathergen/ (accessed on 19 September 2012).

13. Eames, M.; Kershaw, T.; Coley, D. On the creation of future probabilistic design weather years from UKCP09. Build. Serv. Eng. 2010, 32, 127-142.

14. ISO (International Organization for Standardization). Task Group 4: Life Cycle Costs in Construction. In LCC as a contribution to sustainable construction-Final; David Langdon Management Consulting: London, UK, 2003. Available online: www.ceetb.eu/docs/Reports/LCC FINAL REPORT-2.pdf (accessed on 15 February 2013).

15. Sodagar, B.; Rai, D.; Murphy, J.; Altan, H. The role of eco-refurbishment in sustainable construction and built environment. In Proceedings of the 3rd CIB International Conference on Smart and Sustainable Built Environments, Delft, The Netherlands, 15-19 June 2009.

16. Bolton, P. Energy Price Rises and Their Impact on Demand-Commons Library Standard Note. Available online: http://www.parliament.uk/briefing-papers/SN04850 (accessed on 19 September 2012).

17. Friends of the Earth. Available online: http://www.foe.co.uk/resource/briefings/gas_price briefing.pdf (accessed on 19 September 2012).

18. Ellingham, I.; Fawcett, W. The option to refurbish. In New Generation of Whole-Life Costing: Property and Construction Decision-Making under Uncertainty; Taylor \& Francis: New York, NY, USA, 2006; pp. 140-141.

19. DECC (Department of Energy and Climate Change). Available online: http://www.decc.gov.uk/en/content/cms/statistics/energy_stats/prices/prices.aspx (accessed on 19 September 2012).

20. Hanton, A. Small Number with Surprisingly Large Consequences - Why the Government Choice of Discount Rate Should Interest Everyone. Available online: http://www.storage.co.uk /downloads/a-small-number.pdf (accessed on 10 Aug 2012).

21. Green Book. Available online: http://www.hm-treasury.gov.uk/d/green_book_complete.pdf (accessed on 19 September 2012).

(C) 2013 by the authors; licensee MDPI, Basel, Switzerland. This article is an open access article distributed under the terms and conditions of the Creative Commons Attribution license (http://creativecommons.org/licenses/by/3.0/). 